University of Chicago Law School

Chicago Unbound

Journal Articles

Faculty Scholarship

2017

\title{
The Structural Function of the Sixth Amendment Right to Counsel of Choice
}

John Rappaport

Follow this and additional works at: https://chicagounbound.uchicago.edu/journal_articles

Part of the Law Commons

\section{Recommended Citation}

John Rappaport, "The Structural Function of the Sixth Amendment Right to Counsel of Choice," 2017 Supreme Court Review 117 (2017).

This Article is brought to you for free and open access by the Faculty Scholarship at Chicago Unbound. It has been accepted for inclusion in Journal Articles by an authorized administrator of Chicago Unbound. For more information, please contact unbound@law.uchicago.edu. 
JOHN RAPPAPORT

THE STRUCTURAL FUNCTION OF

THE SIXTH AMENDMENT RIGHT

TO COUNSEL OF CHOICE

The Sixth Amendment guarantees "the accused," "[i]n all criminal prosecutions," "the Assistance of Counsel for his defence." The right to court-appointed, publicly funded counsel this language calls to mind today is a recent invention. ${ }^{2}$ The "root meaning" of the Sixth Amendment's Counsel Clause, the Supreme Court has stressedthe one with ties to the founding tradition - is the right to retain counsel of one's choice. ${ }^{3}$ Yet until just last Term, no criminal defendant had ever persuaded the Court to reverse a conviction solely on counsel-of-choice grounds; many had tried in vain. I consider in this article whether there is any satisfying, functional account that can explain the disjuncture between what the Court says about the

\footnotetext{
John Rappaport is Assistant Professor of Law, The University of Chicago Law School.

Author's note: The article benefited from excellent comments from Will Baude, Rich Chen, Andrew Crespo, Richard McAdams, Michael Morley, and Geof Stone, as well as presentation at the Loyola Constitutional Law Colloquium. Thanks to Matt Enloe, Jorgen Rehn, and especially Hannah Gelbort for helpful research assistance and to the Darelyn A. \& Richard C. Reed Memorial Fund for financial support.

${ }^{1}$ US Const, Amend VI.

${ }^{2}$ See Gideon v Wainwright, 372 US 335 (1963).

${ }^{3}$ United States v Gonzalez-Lopez, 548 US 140, 147-48 (2006). See also Kaley v United States, 134 S Ct 1090, 1102 (2014).

(C) 2017 by The University of Chicago. All rights reserved. 978-0-226-49084-7/2017/2016-0004\$10.00
} 
right to counsel of choice and what it does when presented with an asserted violation of that right.

The leading academic and judicial theories justify the right to counsel of choice either as securing the effective assistance of counsel, and thus a fair trial, or as a facet of the defendant's prerogative to control his own defense. These theories, however-grounded in majestic-sounding notions of fairness and autonomy, respectivelystruggle to explain counsel-of-choice doctrine. For one thing, indigent defendants - who number more than four out of every five - simply have no right to choose their counsel at all. And while criminal procedure rights are seldom absolute, balancing the defendant's fairness and autonomy interests against the government's countervailing needs cannot explain the pattern of Court decisions in anything but the most ad hoc manner. Seemingly unremarkable governmental interests prevail while a stronger one faltered this past Term.

My claim is that something very different makes sense of the Supreme Court's counsel-of-choice decisions. The failure of the leading theories, therefore, does not condemn the doctrine to incoherence. The right to counsel of choice, I argue, functions not as a powerful individual entitlement, as much of the judicial and scholarly writing suggests, but rather as a weak, system-level safeguard against socialization of the criminal defense bar. I use "socialization" here to refer to "the action or process of bringing" an institution "under state ownership or public control"- that is, not in the sense of social psychology but rather the political theory of socialism. ${ }^{4}$ Only when the government advances a theory for restraining defendant choice that, if accepted, would allow it to strangle the private defense bar and socialize criminal defense does this antisocialization principle require that the right to counsel of choice prevail. This means that even a weak governmental interest-like a judge's desire to push a case to trial quickly - can overcome the right as long as that interest is meaningfully bounded in its reach across the criminal docket. But it also means that a law requiring all defendants to use court-appointed counselmandating a socialized defense bar-would violate the Sixth Amendment despite its equality-promoting effects.

An antisocialization principle explains, in particular-far better than a theory grounded in individual fairness or autonomy-last

${ }^{4}$ Oxford English Dictionary (Oxford, 3d ed 2009), archived at https://perma.cc/Q2LJ -UESL. 
Term's counsel-of-choice decision, Luis v United States, ${ }^{5}$ in which the Court for the first time found a stand-alone counsel-of-choice violation. The defendant in Luis was charged with health care fraud of around $\$ 45$ million, almost all of which she had already spent. Seeking to preserve the $\$ 2$ million remaining in the defendant's possession, which would be necessary to pay restitution and criminal penalties if the defendant were convicted, the government obtained a pretrial order prohibiting the defendant from dissipating her assets. This included the defendant's "untainted" assets - assets not traceable to her alleged crimes - which the defendant wished to spend to mount her criminal defense. ${ }^{6}$

Reversing the Eleventh Circuit Court of Appeals, a fractured Supreme Court held that the trial court's order violated the defendant's Sixth Amendment right to counsel of choice. Justice Breyer announced the Court's judgment in a four-Justice plurality opinion, joined by Chief Justice Roberts and Justices Ginsburg and Sotomayor. Justice Thomas concurred in the judgment, resting on a textual and historical analysis. Justice Kennedy, joined by Justice Alito, dissented, finding the case indistinguishable from precedent that had rebuffed similar counsel-of-choice claims. Justice Kagan also dissented, questioning whether that same precedent had been correctly decided.

An antisocialization theory - but neither fairness nor autonomycogently distinguishes Luis from all of the cases in which the Court rejected counsel-of-choice claims. That includes the two famous and closely related precedents the Justices in the majority strained to differentiate in Luis, ${ }^{7}$ ultimately relying on unpersuasive statutory and historical formalisms that I will examine. Antisocialization can also begin to explain (though not necessarily justify) the complete denial of the counsel-of-choice right to indigent criminal defendants, a disquieting feature of the doctrine in light of equal-protection principles.

I explore these issues below. Part I introduces the leading theories courts and commentators have developed to justify the right to counsel of choice. It then exposes the inability of these theories to

\footnotetext{
${ }^{5} 136$ S Ct 1083 (2016).

${ }^{6}$ Id at 1087-88 (Breyer, J) (plurality).

${ }^{7}$ Caplin \& Drysdale, Chartered v United States, 491 US 617 (1989); United States v Monsanto, 491 US 600 (1989).
} 
explain the doctrine. Part II demonstrates how an antisocialization theory better describes the law. In the tradition of criminal procedure scholarship seeking theories that reconcile the Court's decisions, ${ }^{8} \mathrm{I}$ do not argue that antisocialization ought to drive the doctrine; my project is positive, not normative. I seek to explain the law, not to justify it. Nevertheless, I do develop in Part II a plausible normative defense for the antisocialization theory in order to bolster my descriptive claim. The defense is sufficient to persuade me that Luis was correctly decided. Were I to craft my own justification for the counsel-of-choice right, however, it might well be markedly more robust.

My argument is not that antisocialization is the only fathomable theory that explains the doctrine. It is possible, for example, that counsel-of-choice doctrine tracks historical understandings of the right. Yet neither the Justices nor commentators have shown this to be generally true, leaving the burden of proof, for the time being, on the historical theory's would-be proponents. I am skeptical, though, I will add, that a historical theory would be as useful as the functional theory I explicate here, confronting, as it must, the familiar problem of what to do when formal materials (i.e., historical understandings) run out.'

In Part III, in lieu of a traditional conclusion, I step outside the Sixth Amendment to critique counsel-of-choice doctrine from an external perspective. The doctrine itself is young and undertheorized, and much remains to be worked out in due course. But regardless of how the Court resolves any outstanding Sixth Amendment questions, I argue in Part III that several of its counsel-of-choice precedents may run aground on other, settled constitutional protections. These are conflicts the Court should consider alongside Sixth Amendment principles as it continues to elaborate the right to counsel of choice.

\footnotetext{
${ }^{8}$ See, for example, William J. Stuntz, Self-Incrimination and Excuse, 88 Colum L Rev 1227, 1231-32 (1988) (arguing that "a great deal of the doctrine is consistent with what the Justices would have done had they ... viewed the privilege" against self-incrimination in light of the author's excuse theory); Peter Westen and Richard Drubel, Toward a General Theory of Double Jeopardy, 1978 Supreme Court Review 81, 155 (offering a descriptive theory of doublejeopardy law and arguing that " $[\mathrm{t}]$ he measure of a theory is its usefulness in explaining the data - in this case the decisions of the Supreme Court").

' See Michael W. McConnell, Time, Institutions, and Interpretation, 95 BU L Rev 1745, 1761 (2015) (acknowledging, as an originalist, that "[w]hen history runs out, we have to use other methods of interpretation").
} 


\section{Difficulties with the Leading Descriptive Theories}

Two principal theories - what I call fairness and autonomydominate judicial and scholarly thinking on the right to counsel of choice. Yet however well these theories might justify the right as a philosophical matter, they cannot explain counsel-of-choice doctrine. In this part, I describe the fairness and autonomy theories and illustrate the limits of their descriptive power. In particular, I show how these theories are unable cogently to distinguish Luis, in which the Court found a stand-alone violation of the defendant's right to counsel of choice, from the many cases in which it did not. ${ }^{10}$

\section{A. FAIRNESS}

Probably the most popular theory of counsel of choice describes the right as helping the defendant secure a fair trial. This fairness theory is outcome-oriented and instrumental — it regards the right as a means to the ultimate end of fair adjudication in an adversary system. Perhaps more precisely, the fairness theory views the right to counsel of choice as securing the right to effective assistance of counsel, which itself ensures a fair adjudicatory process.

The plurality opinion in Luis (to the extent it is theorized at all) seems to rest upon this understanding. Although it acknowledges that the entitlement at stake is that to "counsel of choice," the plurality elides that right with the more "fundamental" right to counsel itself, without which the defendant, "though he be not guilty, ... faces the

\footnotetext{
${ }^{10}$ There are several well-known decisions my analysis does not cover. In Gonzalez-Lopez $v$ United States, 548 US 140 (2006), the case in which the Court first called the right to counsel of choice the "root meaning" of the Counsel Clause, the government had conceded a counsel-of-choice violation; the Court did not consider whether one had occurred. Id at 144. There are also two cases in which the Court is sometimes said to have found a violation of the right to counsel of choice, but which in fact involved deprivation of the right to counsel itself. See Glasser v United States, 315 US 60, 76 (1942) (holding that the trial court had denied the defendant "his right to have the effective assistance of counsel" by appointing the defendant's attorney to represent another defendant simultaneously); Powell v Alabama, 287 US 45, 58 (1932) (holding that defendants charged with rape "were not accorded the right of counsel in any substantial sense"). On Powell, see also United States v Cronic, 466 US 648, 660-61 (1984) (characterizing Powell as a case in which "the likelihood that counsel could have performed as an effective adversary was so remote as to have made the trial inherently unfair"); Lawrence M. Friedman, Crime and Punishment in American History 299, 376 (Basic, 1993) (describing the rape charge as "a complete fabrication" and the trial as "a scandal . . . thick with race prejudice" and asserting that "the defendants, practically speaking, had no help at all from their lawyers"); Janet C. Hoeffel, Toward a More Robust Right to Counsel of Choice, 44 San Diego L Rev 525, 529 (2007) ("Powell was not a case about right to counsel of choice.").
} 
danger of conviction because he does not know how to establish his innocence." ${ }^{11}$ Elsewhere the Court has "recognized that the purpose of providing assistance of counsel 'is simply to ensure that criminal defendants receive a fair trial," and thus, "while the right to select and be represented by one's preferred attorney is comprehended by the Sixth Amendment, the essential aim of the Amendment is to guarantee an effective advocate for each criminal defendant." 12

There is a related position, which is sometimes portrayed as independent from the fairness theory, but which seems to me sufficiently related to warrant common treatment. That view regards the right to counsel of choice as facilitating a "meaningful relationship" between counsel and her client. The idea is that a criminal defendant will place greater trust in, and form a better relationship with, a lawyer he has selected rather than one the court has thrust upon him. ${ }^{13}$ Upon inspection, however, most formulations of the "meaningful relationship" position are grounded in the belief that a better attorney-client relationship will enable a stronger defense. ${ }^{14}$ The relationship is typically not thought to be valuable in its own right.

Some argue that good attorney-client relationships help legitimize case outcomes - that defendants will accept their fate more readily if they believe they received zealous representation from counsel they

\footnotetext{
${ }^{11}$ Luis, 136 S Ct at 1088-89 (Breyer, J) (plurality) (quotation mark omitted), quoting Gideon $v$ Wainwright, 372 US 335, 345 (1963), quoting Powell, 287 US at 69.

${ }^{12}$ Wheat $v$ United States, 486 US 153, 159 (1988), quoting Strickland v Washington, 466 US 668, 689 (1984). See also, for example, Bruce A. Green, Lethal Fiction: The Meaning of "Counsel" in the Sixth Amendment, 78 Iowa L Rev 433, 441 (1993) ("The right to choose counsel promotes the fairness and reliability of criminal proceedings. . ..").

${ }^{13}$ See, for example, Luis, 136 S Ct at 1089 (Breyer, J) (plurality); Green, 78 Iowa L Rev at 441 (cited in note 12); Hoeffel, 44 San Diego L Rev at 527, 542 (cited in note 10); Wayne D. Holly, Rethinking the Sixth Amendment for the Indigent Criminal Defendant: Do Reimbursement Statutes Support Recognition of a Right to Counsel of Choice for the Indigent?, 64 Brooklyn L Rev 181, 187-88, 207 (1998); Bruce J. Winick, Forfeiture of Attorneys' Fees Under RICO and CCE and the Right to Counsel of Choice: The Constitutional Dilemma and How to Avoid It, $43 \mathrm{U}$ Miami L Rev 765, 802 (1989).

${ }^{14}$ See, for example, Caplin \& Drysdale, Chartered v United States, 491 US 617, 645 (1989) (Blackmun, J, dissenting) (referring to "the trust between attorney and client that is necessary for the attorney to be a truly effective advocate"); Morris $v$ Slappy, 461 US 1, 21 (1983) (Brennan, J, concurring in result) (asserting that "crucial decisions" of trial strategy "can best be made, and counsel's duties most effectively discharged, if the attorney and the defendant have a relationship characterized by trust and confidence"); Alfredo Garcia, The Right to Counsel Under Siege: Requiem for an Endangered Right?, 29 Am Crim L Rev 35, 95 (1991) (“An inextricable link exists between the confidence and trust a criminal defendant has in his lawyer and the effectiveness of the defense attorney."); Hoeffel, 44 San Diego L Rev at 541 (cited in note 10); Holly, 64 Brooklyn L Rev at 188 (cited in note 13); Winick, 43 U Miami L Rev at 802-04 (cited in note 13).
} 
selected. ${ }^{15}$ To the extent the outcomes being legitimized are substantively fair, this seems reasonable to me, though not meaningfully distinct from the fairness theory itself. To the extent that unfair outcomes will appear legitimate, it is far less clear that this plausibly justifies the right.

\section{B. AUTONOMY}

A second strand of legal thought - absent in Luis - maintains that the right to counsel of choice has intrinsic value as an aspect of the criminal defendant's individual autonomy and control over his own defense. Unlike the fairness theory, this autonomy theory is not outcome-oriented; it does not depend on an assumption or prediction about how counsel will affect the fairness or result of the defendant's proceedings. The right to counsel of choice, on this view, is valuable for its own sake, not because of the results it's thought to produce. ${ }^{16}$

The Supreme Court's opinion in Gonzalez-Lopez v United States ${ }^{17}$ exemplifies the autonomy position. The Sixth Amendment "commands," the Court admonished in Gonzalez-Lopez, "not that a trial be fair, but that a particular guarantee of fairness be provided - to wit, that the accused be defended by the counsel he believes to be best."18 This "right to select counsel of one's choice," the Court continued, "has never been derived from the Sixth Amendment's purpose of ensuring a fair trial" and should not be confused with the "right to effective counsel." 19 It "reflects constitutional protection of the defendant's free choice independent of concern for the objective fairness of the proceeding." ${ }^{20}$

\footnotetext{
${ }^{15}$ See, for example, Caplin \& Drysdale, 491 US at 645 (Blackmun, J, dissenting) ("[T]he defendant's perception of the fairness of the process, and his willingness to acquiesce in its results, depend upon his confidence in his counsel's dedication, loyalty, and ability."); Garcia, 29 Am Crim L Rev at 96-97 (cited in note 14); Winick, 43 U Miami L Rev at 802 (cited in note 13).

${ }^{16}$ For a thorough normative defense of the criminal defendant's autonomy interest, see Erica J. Hashimoto, Resurrecting Autonomy: The Criminal Defendant's Right to Control the Case, 90 BU L Rev 1147 (2010). For a skeptical take, see Robert E. Toone, The Incoherence of Defendant Autonomy, 83 NC L Rev 621 (2005).

${ }^{17} 548$ US 140 (2006).

${ }^{18} \mathrm{Id}$ at 146.

${ }^{19} \mathrm{Id}$ at $147,148$.

${ }^{20}$ Flanagan v United States, 465 US 259, 268 (1984). Of course, some jurists subscribe to both the fairness and autonomy views. See, for example, Wheat, 486 US at 165-66 (Marshall, J, dissenting) (arguing that "a primary purpose of the Sixth Amendment is to grant a
} 
Much scholarly commentary on the right to counsel of choice accords with this view, agreeing that "the most important decision a defendant makes in shaping his defense is his selection of an attorney." ${ }^{21}$ The attorney acts, among other things, as conduit for the defendant's "communicative activity in the public forum of the courtroom"; respect for the defendant's choice of counsel is thus " 'respect for the individual'" himself. ${ }^{22}$ One commentator, analogizing to the right to self-representation, aptly quoted the Court's sharp language from that context: "An unwanted counsel 'represents' the defendant only through a tenuous and unacceptable legal fiction. Unless the accused has acquiesced in such representation, the defense presented is not the defense guaranteed by the Constitution, for, in a very real sense, it is not his defense." ${ }^{23}$

\section{THE THEORIES' DESCRIPTIVE SHORTCOMINGS}

The fairness and autonomy theories for the right to counsel of choice are perfectly lucid as a philosophical matter. What they lack, however, is any real explanatory power. If the theories did explain the doctrine, they would be able to distinguish Luis, in which the Court found a counsel-of-choice violation, from the many cases in which it did not. Yet as I show in this section, neither theory is up to this task. Specifically, neither theory is able persuasively to differ-

criminal defendant effective control over the conduct of his defense" because "it is he who suffers the consequences if the defense fails," but also that "lodging the selection of counsel with the defendant generally will promote the fairness and integrity of criminal trials"), quoting Faretta v California, 422 US 806, 819-20 (1975).

${ }^{21}$ Winick, 43 U Miami L Rev at 803 (cited in note 13), quoting United States v Laura, 607 F2d 52, 56 (3d Cir 1979); Holly, 64 Brooklyn L Rev at 189 (cited in note 13).

${ }^{22}$ Winick, $43 \mathrm{U}$ Miami L Rev at 803 (cited in note 13), quoting Wilson v Mintzes, $761 \mathrm{~F} 2 \mathrm{~d}$ 275, 286 (6th Cir 1985). Public defense reformers, by developing a "client-centered" model of representation, have worked to effectuate defendant autonomy even when defendants cannot choose their counsel. See, for example, Robin Steinberg and David Feige, Cultural Revolution: Transforming the Public Defender's Office, 29 NYU Rev L \& Soc Change 123 (2004).

${ }^{23}$ Winick, 43 U Miami L Rev at 804 (cited in note 13) (quotation marks omitted), quoting Faretta, 422 US at 821 . For additional academic commentary supporting the autonomy theory, see Garcia, 29 Am Crim L Rev at 92-98 (cited in note 14); Green, 78 Iowa L Rev at 442 (cited in note 12); Hoeffel, 44 San Diego L Rev at 543-44 (cited in note 10); Eugene L. Shapiro, The Sixth Amendment Right to Counsel of Choice: An Exercise in the Weighing of Unarticulated Values, 43 SC L Rev 345, 385 (1992); Note, Rethinking the Boundaries of the Sixth Amendment Right to Choice of Counsel, 124 Harv L Rev 1550, 1571 (2011). 
entiate Luis from three sets of counsel-of-choice precedents that capture most, if not all, of the Supreme Court's work in this domain: (1) cases involving the inherent powers of the trial court to control litigation; (2) fee-forfeiture cases involving "tainted" (rather than "untainted") assets; and (3) cases involving indigent criminal defendants.

1. Inherent powers. Mundane decisions courts make in the course of criminal litigation, or even antecedent choices regarding judicial administration, can have the effect of denying a criminal defendant his first-choice aide. Consider three examples. In one case, the court denies a midtrial continuance necessary to accommodate the desired attorney's schedule. In another, it prohibits counsel from representing the defendant alongside two of his codefendants, notwithstanding conflict-of-interest waivers from all of the defendants concerned. And in the third, it simply enforces court rules barring practice by nonlawyers, disbarred lawyers, and lawyers from out of state.

In none of these cases, the Court has said, does the trial court violate the defendant's right to counsel of choice. ${ }^{24}$ But the trial court's actions in each instance certainly implicate the defendant's fairness and autonomy interests. The defendant who was denied a continuance, for example, argued that the lawyer assigned to him had not zealously represented his interests. ${ }^{25}$ Disagreeing, the Court denied his claim and expressly rejected the lower court's position, rooted in the fairness theory, that the right to counsel of choice safeguards a "meaningful relationship" between the defendant and his attorney. ${ }^{26}$ Likewise, deciding to roll the dice with a lay representative ${ }^{27}$ or

\footnotetext{
${ }^{24}$ See Wheat, 486 US at 159 (conflict of interest); Slappy, 461 US at 13 (continuance); Note, 124 Harv L Rev at 1554 (cited in note 23) ("No Supreme Court case has turned directly on the question of whether choice of counsel may be limited entirely to current members of the bar, but the Court has clearly asserted this much in dicta."). But see, for example, United States v Whitesel, 543 F2d 1176, 1179 (6th Cir 1976) (rejecting strict equation of "counsel" with "attorneys at law").

${ }^{25}$ Slappy, 461 US at 8.

${ }^{26} \mathrm{Id}$ at $13-14$.

${ }^{27}$ See, for example, Green, 78 Iowa L Rev at 470-71 (cited in note 12); Mindy D. Block, Comment, The Criminal Defendant's Sixth Amendment Right to Lay Representation, 52 U Chi L Rev 460, 470 (1985). See also Faretta, 422 US at 820 n 16 (observing that "[t]he first lawyers were personal friends of the litigant, brought into court by him so that he might 'take "counsel" with them' before pleading," and "the first 'attorneys' were personal agents, often lacking any professional training"), quoting Frederick Pollock and Frederic William Maitland, 1 The History of English Law Before the Time of Edward I 211 (Cambridge, 2d ed 1898).
} 
one subject to a potential conflict of interest ${ }^{28}$ would seem to fall squarely within the autonomy-premised right to control one's defense. This is the same interest, notably, that supports the right to self-representation, which requires the trial court to let an uneducated defendant represent himself. ${ }^{29}$ At the very least, these outcomes are difficult to reconcile with the type of robust individual protection the Court's "root meaning" language implies.

Of course, observing that the right fails in some cases to protect the defendant's interests - whether rooted in fairness or autonomymay suggest nothing more than that those interests were outweighed by the government's countervailing needs through a process of interest-balancing. Yet if counsel-of-choice doctrine reflects a weighing of fairness or autonomy interests, on the one hand, and government need, on the other, we would expect the government to prevail when it matters most and lose when it matters least-especially as the defendants' interests seem roughly equivalent across the cases. ${ }^{30}$

The doctrine does not line up this way, however. This is a point that was harder to see before Luis, because the government's interests had prevailed in every case. That they fell short in Luis suggestsif the doctrine indeed reflects a balance of the defendant's fairness or autonomy interests against state prerogatives - that the government interest in Luis was weaker than in all the prior cases. But that is a difficult position to maintain. In the earlier cases, the government won by asserting interests such as the "great deal of latitude" necessary "in scheduling trials," ${ }^{31}$ the desire to ensure that "legal proceedings appear fair to all who observe them," ${ }^{32}$ and "the legitimate wish of district courts that their judgments remain intact on appeal." ${ }^{33}$ In Luis, it had what the Court has elsewhere characterized as a "strong governmental interest in obtaining full recovery of all for-

\footnotetext{
${ }^{28}$ See Bruce A. Green, "Through a Glass, Darkly": How the Court Sees Motions to Disqualify Criminal Defense Lawyers, 89 Colum L Rev 1201, 1233-38 (1989) (criticizing the Court's conflict-of-interest precedent on autonomy grounds).

${ }^{29}$ Faretta, 422 US at 833.

${ }^{30}$ See Stuntz, 88 Colum L Rev at 1236 (cited in note 8) (making the point for selfincrimination doctrine).

${ }^{31}$ Slappy, 461 US at 11.

${ }^{32}$ Wheat, 486 US at 160.

${ }^{33}$ Id at 161. See Green, 89 Colum L Rev at 1239-48 (cited in note 28) (arguing that the Court's reliance on the institutional interests of the judiciary is misguided).
} 
feitable assets," ${ }^{34}$ which aims to punish and deter serious crimes. ${ }^{35}$ If there is a theory as to why that "strong governmental interest" is actually weaker than the trial court's interest in controlling litigation by, say, denying a continuance, the Court has never disclosed it.

The point is not that balancing is irrelevant, or in no way enhances the explanatory power of the leading theories. Rather, the point is that, to transcend simplistic, ad hoc explanations, balancing - to borrow from Professor William Stuntz - "must reflect some underlying theoretical structure." ${ }^{36}$ Where, as here, the interests on each side of the balance are neither trivial nor overwhelming, "balancing without structure explains all results equally well; it is not so much a positive theory as a confession that no positive theory exists." "Th "The real challenge," I agree with Stuntz, "is to explain why the balances are struck as they are in particular cases, and to do so in a way that allows one to assess, at least in broad terms, whether the doctrine is internally coherent." ${ }^{38}$ Proponents of the fairness and autonomy theories have produced no such explanation, and I am doubtful that they can.

2. Fee forfeiture. A pair of fee-forfeiture cases the Court decided in 1989 framed the issues it considered in Luis. In Caplin \& Drysdale, Chartered $v$ United States, ${ }^{39}$ the Court held that the Sixth Amendment permits Congress to authorize postconviction forfeiture of so-called "tainted" assets, traceable to criminal activity, even when the defendant seeks to spend the assets to pay the lawyers who defended him. ${ }^{40}$ The same thing goes, the Court said in United States $v$ Monsanto, ${ }^{41}$ for a pretrial order freezing assets the government alleges are tainted and therefore forfeitable. ${ }^{42}$

\footnotetext{
${ }^{34}$ Caplin \& Drysdale, Chartered v United States, 491 US 617, 631 (1989). The plurality in Luis characterized this governmental interest as lying fairly far from the "heart of a fair, effective criminal justice system." 136 S Ct at 1093 (Breyer, J) (plurality). Of course, the same can be said, probably more strongly, of the government interests asserted in the prior cases.

${ }^{35}$ On the forfeiture statute's aims, see Winick, 43 U Miami L Rev at 833-34 (cited in note 13).

${ }^{36}$ Stuntz, 88 Colum L Rev at 1237 (cited in note 8).

${ }^{37} \mathrm{Id}$ (citation omitted).

${ }^{38} \mathrm{Id}$.

${ }^{39} 491$ US 617 (1989).

${ }^{40}$ Id at $632-33$.

${ }^{41} 491$ US 600 (1989).

${ }^{42} \mathrm{Id}$ at 616.
} 
The Court's reasoning went like this: (1) tainted assets, though in the defendant's possession, are "not rightfully his," and (2) the defendant has "no Sixth Amendment right to spend another person's money for services rendered by an attorney, even if those funds are the only way that that defendant will be able to retain the attorney of his choice." ${ }^{43}$ Put another way, "impecunious defendants have [no] Sixth Amendment right to choose their counsel," and a defendant whose assets are tainted properly counts as "impecunious." 44

Any tainted assets, it bears noting, will not be proven forfeitable until conviction, by which time the defense attorneys, having rendered services, will have established an interest in them. Yet through a statutory relation-back provision, title in the tainted assets vests in the United States at the time of the criminal act triggering forfeiture, giving the government a claim to the assets superior to the lawyers' ${ }^{45}$ And the pretrial order in Monsanto-entered, of course, long before conviction - is analogous to pretrial detention of the defendant himself. It is, in other words, a restraint on the defendant's property "to protect its 'appearance' at trial and protect the community's interest in full recovery of any ill-gotten gains." ${ }^{46}$

It seems uncontroversial to say that the restraint of assets with which a criminal defendant wishes to pay his attorney intrudes on the fairness and autonomy interests the right to counsel of choice is said to protect. Rendered indigent, or at least less wealthy, the defendant may be forced to proceed with less-qualified counsel and fewer total defense resources, weakening his ability to compete with the prosecution in an adversarial setting and depriving him of some control over his own defense. If the fairness and autonomy theories are to explain these cases, therefore, it must be because the "strong governmental interest in obtaining full recovery of all forfeitable assets" outweighs the defendants' interests. ${ }^{47}$ And indeed, considered in isolation, this does not seem like a far-fetched proposition. The principal difficulty is how to reconcile these earlier cases with the defendant's victory in Luis. Neither the fairness nor the autonomy theory explains why the Court reached the opposite result in that case.

\footnotetext{
${ }^{43}$ Caplin \& Drysdale, 491 US at 626.

${ }^{44} \mathrm{Id}$ at 624.

${ }^{45}$ Id at 626-28.

${ }^{46}$ Monsanto, 491 US at 615-16.

${ }^{47}$ Caplin \& Drysdale, 491 US at 631.
} 
The key distinction between Monsanto and Luis - to focus on the closest cousins - is that Monsanto involved the restraint of allegedly tainted assets, but in Luis the money was concededly clean. ${ }^{48}$ How does that affect the Sixth Amendment analysis under the fairness and autonomy theories? As an initial matter, whether the assets are tainted does not affect the defendant's fairness and autonomy interests. Her interests in controlling her defense and obtaining a fair adjudication are the same regardless of what kind of money she seeks to spend. The explanation, if there is one, must instead be that the government's argument for recovering tainted assets is stronger than for untainted assets. The Luis plurality can be read to take this position. Its formalistic reasoning, however, is unpersuasive - at least to one in search of a functional theory.

The plurality characterized the distinction between tainted and untainted assets as "the difference between what is yours and what is mine." ${ }^{49}$ Under the statutory relation-back provision, the plurality reminded, title to tainted assets passes to the government at the time the crime is committed. ${ }^{50}$ The same is not true, it implied, ${ }^{51}$ of untainted assets: "regarding her untainted assets," the defendant can, before trial, "reasonably claim that the property is still 'mine,' free and clear." ${ }_{22}$ This move allowed the plurality to characterize the government's interest in "obtaining payment of a criminal forfeiture or restitution order" using untainted assets as "contingent," lacking in "constitutional protection," and, compared to the right to counsel of choice, "further from the heart of a fair, effective criminal justice system." 53

The distinction between tainted and untainted assets cannot bear the weight the plurality puts upon it..$^{54}$ First, while it is true that the government does not own forfeitable untainted assets before con-

\footnotetext{
${ }^{48}$ The government went after the defendant's "substitute" assets in Luis because, it alleged, the defendant had already spent the proceeds of her crime - the kind of "tainted" assets held forfeitable in Caplin \& Drysdale and Monsanto. See Luis, $136 \mathrm{~S} \mathrm{Ct}$ at 1087-88 (Breyer, J) (plurality).

${ }^{49}$ Id at 1091.

${ }^{50}$ Id at 1092, citing 21 USC $\$ 853$ (c).

${ }^{51}$ But see, for example, United States v McHan, 345 F3d 262, 270-72 (4th Cir 2003).

${ }^{52}$ Luis, $136 \mathrm{~S}$ Ct at 1092 (Breyer, J) (plurality).

${ }^{53} \mathrm{Id}$ at 1093 .

${ }^{54}$ This is not to deny that the distinction mattered at common law, or that it retains significance in certain legal contexts today.
} 
viction, the same is true of forfeitable tainted assets. What the Court consistently calls "tainted" assets are, after all, only allegedly tainted assets. ${ }^{55}$ Until conviction, "[t]he defendant maintains ownership of either type, with the Government holding only a contingent interest." ${ }^{56}$ What made the pretrial order constitutionally permissible in Monsanto is that the defendant's assets were (prima facie) forfeitable, not that they were tainted. ${ }^{57}$ The assets in that case happened to be forfeitable because they were tainted, but that does not mean that assets Congress deems forfeitable for some other reason-such as to substitute for tainted assets already dissipated - are of a different constitutional order.

Put another way, to say the government can freeze tainted but not untainted assets is to beg the question. The purpose of the trial-in either case - is to determine whether the assets are the defendant's or are instead forfeitable because the defendant committed a crime. Before trial, when the assets are restrained, the answer to this question is unknown. The reason the Monsanto Court thought tainted assets aren't "the defendant's" up until conviction was simply that Congress said so-Congress said they could be frozen upon a showing of probable cause. ${ }^{58}$ Congress said the exact same thing here, with respect to untainted, substitute assets. ${ }^{59}$

Second, the relation-back doctrine-which the Luis plurality seemed to think applies to tainted but not untainted assets - is beside the point. "The doctrine's purpose is to prevent defendants from avoiding forfeiture by transferring their property to third parties"; it does not, however, "alter the time at which title to forfeitable property passes to the Government." ${ }^{\circ 0}$ Nor is it clear why Congress's statutory treatment of property is relevant to a Sixth Amendment

\footnotetext{
${ }^{55}$ See id at 1112 (Kagan, J, dissenting) (“'T] he plurality's use of the word 'tainted,' to describe assets at the pre-conviction stage, makes an unwarranted assumption about the defendant's guilt. Because the Government has not yet shown that the defendant committed the crime charged, it also has not shown that allegedly tainted assets are actually so.") (citation omitted).

${ }^{56} \mathrm{Id}$; id at 1106-07 (Kennedy, J, dissenting).

${ }^{57}$ See Monsanto, 491 US at 615; United States $v$ Wingerter, 369 F Supp 2d 799, 810 (ED Va 2005).

${ }^{58}$ Monsanto, 491 US at 611-14, discussing 21 USC $\$ 853(\mathrm{e})$.

${ }^{59}$ See Luis, $136 \mathrm{~S}$ Ct at 1108 (Kennedy, J, dissenting), discussing 18 USC $\$ 1345$.

${ }^{60}$ Luis, $136 \mathrm{~S}$ Ct at 1107 (Kennedy, J, dissenting). See also Winick, 43 U Miami L Rev at 835 (cited in note 13) (discussing legislative history).
} 
analysis. If relation-back applies only to tainted assets, that fact is simply a matter of "congressional whim[ ]." ${ }^{61}$ It is hard to imagine that, if Congress extended relation-back to untainted, substitute assets, the plurality would change its tune. But that is what the logic of its analysis implies.

Finally, because money is fungible, "the plurality's approach leads to utterly arbitrary distinctions as among criminal defendants who are in fact guilty." ${ }^{2}$ To borrow an example from Justice Kennedy's dissent, imagine a thief who steals $\$ 1$ million and wins another $\$ 1$ million in a lottery. If he spends his lottery winnings on fancy cars and meals, and then needs money for defense counsel, he's out of luck; the government can restrain the stolen funds. But if he spends the stolen money first, he can use the lottery winnings to pay an attorney. ${ }^{63}$ This is senseless: "the Government's and the defendant's respective legal interests" in the two pots of money-tainted and untainted- " are exactly the same." ${ }^{64}$

Justice Thomas's concurring opinion, I should add, fares no better. Thomas argued, essentially, that the original understanding of the Counsel Clause protects the defendant's right to spend his money to employ a defense attorney; that that right necessarily implies some limit on the government's ability to restrain the defendant's assets before trial; and that the common-law practice permitting pretrial restraint of tainted but not untainted assets supplies that necessary limit. ${ }^{65}$

There are several problems with Justice Thomas's position for my purposes. First, Thomas expressly eschews any interest in an analysis that demands functional reasons for the distinctions it draws. ${ }^{66}$ Historical practice is Thomas's lodestone, however much (or little) sense it makes. Second, it is far from clear that Justice Thomas advances a theory of the Sixth Amendment at all, as opposed to a theory about the due process prerequisites to the restraint of any individual's untainted assets. Thomas argues that a defendant's untainted assets

\footnotetext{
${ }^{61}$ Luis, $136 \mathrm{~S}$ Ct at 1108 (Kennedy, J, dissenting).

${ }^{62} \mathrm{Id}$ at 1113 (Kagan, J, dissenting), citing id at 1108-09 (Kennedy, J, dissenting).

${ }^{63} \mathrm{Id}$ at 1103 (Kennedy, J, dissenting).

${ }^{64} \mathrm{Id}$ at 1112 (Kagan, J, dissenting).

${ }^{65}$ Id at 1096-97 (Thomas, J, concurring in judgment).

${ }^{66} \mathrm{Id}$ at 1101.
} 
may not be restrained before trial whether he wishes to spend them on a defense attorney or something else entirely. ${ }^{67}$ This suggests that the Sixth Amendment itself is actually doing precious little work. Finally, even if historical practice does adequately reconcile Luis with the prior forfeiture cases, Justice Thomas makes no attempt to show that it also explains the Court's other counsel-of-choice precedents, declining to engage that body of law at all. As I acknowledged at the outset, it remains theoretically possible that all of the Court's decisions happen to align with historical understandings, but I am doubtful, and neither the Court nor commentators have done the work to prove it.

$$
* * *
$$

In sum, because the defendant's interest in counsel of choice is the same regardless whether he wishes to pay his attorney with tainted or untainted assets, the fairness and autonomy theories can explain the forfeiture cases only if the government's side of the balance is weightier in the former case than in the latter. There is, however, no good functional account of why that would be so. The forfeiture cases thus detract significantly from the explanatory power of these leading theories of the right.

3. Indigence. The notion that indigent criminal defendants might retain a Sixth Amendment right to counsel of choice has been, to the Court, a nonstarter. ${ }^{68}$ "It is hornbook law," one commentator wrote, "that indigent defendants have no right to counsel of choice." ${ }^{\circ 9}$ If the dominant theories are correct, this must be because (for reasons absent in Luis) assigning counsel to these defendants is not unfair, does not intrude on autonomy interests, or is justified by overriding governmental interests - or some combination of the three. All of these arguments, however, are weaker than they may at first seem. I address each one in turn.

\footnotetext{
${ }^{67}$ Id at 1099.

${ }^{68}$ See, for example, Gonzalez-Lopez, 548 US at 151 ("[T]he right to counsel of choice does not extend to defendants who require counsel to be appointed for them.”); Caplin \& Drysdale, 491 US at 624 ("Petitioner does not, nor could it defensibly do so, assert that impecunious defendants have a Sixth Amendment right to choose their counsel."); Wheat, 486 US at 159 ("[A] defendant may not insist on representation by an attorney he cannot afford. . . .); Slappy, 461 US at 23 n 5 (Brennan, J, concurring in result) (calling the defendant's "right to choose his own counsel" a "right that indigent defendants do not enjoy").

${ }^{69}$ Vivian O. Berger, The Supreme Court and Defense Counsel: Old Roads, New Paths-A Dead End?, 86 Colum L Rev 9, 49 n 207 (1986).
} 
a) Fairness.-Consider what would have happened to the defendant in Luis had the Court ruled against her and deemed her untainted assets unavailable to pay counsel. There is no suggestion that she would have been forced through trial unaided by "the guiding hand of counsel." ${ }^{\prime 70}$ Of course not. Instead, the court would have appointed an attorney to represent her-either a public defender or a private attorney funded under the Criminal Justice Act. ${ }^{71}$ Such an appointment could have threatened to injure the defendant (under a fairness theory) only if there were an unacceptable risk that appointed counsel would fail to provide the effective assistance of counsel necessary to make the trial fair.

One of two conclusions follows. First, it may be that forcing the defendant to proceed with appointed counsel would not have jeopardized her right to a fair trial, and thus should not have been deemed to violate her right to counsel of choice. Indeed, the Court has repeatedly rejected any presumption that appointed counsel are categorically ineffective or less effective than retained counsel..$^{72}$ Effectiveness must be judged, the Court has instructed, after the fact, on a case-by-case basis. ${ }^{73}$

As an empirical matter, this is not an unreasonable conclusion. One federal government study, for example, found that conviction rates and average sentences were similar for defendants represented by publicly financed and private attorneys. ${ }^{74}$ And federal judges rate public defenders as superior to (and court-appointed counsel as equal

\footnotetext{
${ }^{70}$ Powell, 287 US at 69.

${ }^{71}$ See 18 USC $\$ 3006$ A.

${ }^{72}$ See, for example, Cronic, 466 US at 658 (holding, in a case of appointed counsel, that "we presume that the lawyer is competent to provide the guiding hand that the defendant needs"); Cuyler v Sullivan, 446 US 335, 344 (1980) ("We may assume with confidence that most counsel, whether retained or appointed, will protect the rights of an accused.").

${ }^{73}$ See, for example, Strickland v Washington, 466 US 668 (1984); Cronic, 466 US at 666. But see Lauren Sudeall Lucas, Reclaiming Equality to Reframe Indigent Defense Reform, 97 Minn L Rev 1197, 1216-20 (2013) (discussing preconviction ineffective-assistance-of-counsel claims).

${ }^{74}$ Caroline Wolf Harlow, Special Report: Defense Counsel in Criminal Cases $* 1$ (US Dept of Justice, Bureau of Justice Statistics, Nov 2000), archived at https://perma.cc/8XRU-48RX. See also Richard D. Hartley, Holly Ventura Miller, and Cassia Spohn, Do You Get What You Pay For? Type of Counsel and Its Effect on Criminal Court Outcomes, 38 J Crim Just 1063, 1067 (2010) (determining, based on data from Cook County, Illinois, that type of counsel-public defender versus private attorney-has no statistically significant impact on the court's decision to incarcerate or the defendant's sentence length). For a helpful review of the literature comparing outcomes among different criminal attorney types, as well as an original analysis, see Thomas H. Cohen, Who Is Better at Defending Criminals? Does Type of Defense Attorney Matter in Terms of Producing Favorable Case Outcomes?, 25 Crim Just Pol Rev 29, 32-33 (2014).
} 
to) private criminal defense lawyers. ${ }^{75}$ But such a conclusion - that public and private attorneys are equally effective-would mean that the fairness theory fails to explain the Luis decision.

There is, however, an alternate conclusion one might draw. Perhaps forcing the defendant in Luis to use a public attorney would indeed have exposed her to an unacceptable risk of deficient representation and jeopardized her fair-trial right. After all, crushing resource constraints plague public defense nationwide. ${ }^{76}$ Appointed counsel often work under conditions no paying client would tolerate, and ethical rules discourage. ${ }^{77}$ Some data suggest that results may suffer. ${ }^{78}$ The Court in Luis, on this assumption, narrowly rescued the defendant from "injury by public defender."

On this view, the outcome in Luis was correct. But consider the implications. Appointed counsel is the norm, not the exception, in criminal defense. Roughly 80 percent of all criminal defendantsand probably a higher share of capital defendants - rely on courtappointed lawyers to defend them. ${ }^{80}$ If forcing the defendant in

\footnotetext{
${ }^{75}$ See Richard A. Posner and Albert H. Yoon, What Fudges Think of the Quality of Legal Representation, 63 Stan L Rev 317, 319, 325-26 \& nn 30-31 (2011).

${ }^{76}$ See, for example, Fustice Denied: America's Continuing Neglect of Our Constitutional Right to Counsel $* 50$ (The Constitution Project, National Right to Counsel Committee, Apr 2009), archived at https://perma.cc/N33T-L95J.

${ }^{77}$ See Donald J. Farole Jr. and Lynn Langton, Special Report: County-Based and Local Public Defender Offices, $2007 * 1$ (US Dept of Justice, Bureau of Justice Statistics, Sept 2010), archived at https://perma.cc/6X3B-6QYD ("About three-quarters (73\%) of county-based public defender offices exceeded the maximum recommended limit of cases received per attorney in 2007.”). See also Preeti Lala, Notes from the Field: Challenges of Indigent Criminal Defense, 12 NY City L Rev 203, 224-26 (2008).

${ }^{78}$ See Harlow, Special Report at $* 1$ (cited in note 74) (reporting that, "of those found guilty, higher percentages of defendants with publicly financed counsel were sentenced to incarceration"); Morris B. Hoffman, Paul H. Rubin, and Joanna M. Shepherd, An Empirical Study of Public Defender Effectiveness: Self-Selection by the "Marginally Indigent," 3 Ohio St J Crim L 223 (2005) (finding, based on Colorado data, that public defenders achieved poorer outcomes than their privately retained counterparts); Marian R. Williams, The Effectiveness of Public Defenders in Four Florida Counties, 41 J Crim Just 205, 211 (2013) (demonstrating that, even with an "above-average public defender system," private attorneys in Florida obtain better outcomes than public defenders), citing Marian R. Williams, A Comparison of Sentencing Outcomes for Defendants with Public Defenders versus Retained Counsel in a Florida Circuit Court, 23 Just Sys J 249 (2002).

${ }^{79}$ Consider Judith Resnik, Trial as Error, Furisdiction as Injury: Transforming the Meaning of Article III, 113 Harv L Rev 924 (2000).

${ }^{80}$ See Harlow, Special Report at $* 1$ (cited in note 74); Slamming the Courthouse Doors: Denial of Access to fustice and Remedy in America $* 7$ (ACLU, Dec 2010), archived at https://perma.cc /G5B7-6TWL ("With rare exceptions, defendants facing capital charges cannot afford a lawyer, and therefore rely on the state to appoint an attorney to provide an adequate defense.").
} 
Luis to rely on a public defender would have been unfair, then what of all these other defendants? To explain Luis on a fairness theory, in other words, is to destabilize the whole regime of indigent defense, cracking the very foundation of our contemporary criminal justice system. ${ }^{81}$

The Court can't have it both ways. Either appointed counsel are presumptively effective notwithstanding the constraints under which they operate - in which case the fairness theory cannot explain the outcome in Luis - or they're not, in which case Luis is correct but implicitly acknowledges a constitutional crisis.

b) Autonomy. - If the fairness theory fails to explain the outcome in Luis, perhaps autonomy can fare better. The challenge here is to explain why the assignment of counsel would violate the autonomy interests of the defendant in Luis but not of the myriad indigent defendants. This task is not as easy as it might first seem. After all, at the moment she needed to pay counsel, the defendant in Luis was effectively indigent, her assets having been frozen. ${ }^{82}$ She prevailed by persuading the Court to focus on an earlier time, immediately before the asset freeze, when she still had cash to spend. Yet certainly some other indigent defendants could also point to a previous moment at which they were not indigent, and to the intervening events that led them into poverty. Why is this particular intervention-a pretrial order freezing untainted assets - the only one thought to intrude impermissibly on the defendant's autonomy interests?

The explanation must be that it matters why the defendant is indigent: In Luis, the government reached out and restrained the defendant's money, whereas restraints on the typical indigent defendant's finances (and thus his autonomy) are exogenously determined. This explanation, though, however plausible on the surface, can be sustained only by resort to notoriously slippery conceptual distinctions and arbitrary framing devices.

\footnotetext{
${ }^{81}$ See Luis, $136 \mathrm{~S}$ Ct at 1110 (Kennedy, J, dissenting) ("Given the large volume of defendants in the criminal justice system who rely on public representation, it would be troubling to suggest that a defendant who might be represented by a public defender will receive inadequate representation.”). Consider also Kaley v United States, 134 S Ct 1090, 1102 n 13 (2014) (observing that, if forcing defendants to proceed with appointed counsel-by freezing their assets pretrial- jeopardizes the trial's fairness, "the right way to start correcting the problem is not" by according more procedural protections before the asset restraint, "but by ensuring that the right to effective counsel is fully vindicated" by appointed counsel).

${ }^{82}$ See Luis, $136 \mathrm{~S} \mathrm{Ct}$ at 1110 (Kennedy, J, dissenting) (describing the defendant as someone who "simply cannot afford the legal team she desires").
} 
Consider first some of the ways an indigent criminal defendant may have ended up indigent. Perhaps he was born into poverty, his employer paid him too little, or the bank foreclosed on his home. In each instance, one might argue, some private party, not the government, bears responsibility. In Luis, by contrast, the government, not any private actor, took the defendant's money. But why look at things this way? As an initial matter, if the defendant in Luis had simply been wealthier - if she had had $\$ 100$ million in her accounts instead of \$2 million - she could have afforded private counsel even after the asset freeze. ${ }^{83}$ Why not attribute her inability to retain counsel to her (very relative) impecuniousness - which, of course, may well have resulted from private action - rather than focus on the trial court's order? ${ }^{84}$

More fundamentally, the public/private distinction-which supplies the intuition that the government taking a defendant's money is different from a private party doing so-is, at least in contemporary society, a porous one. Our indigent defendant was born into poverty partly because estate law allows wealthy individuals to bequeath their fortunes to heirs rather than redistributing them widely; his wages were too low partly because labor and employment law required no more; and he lost his home partly because financial regulations permitted subprime lending to unqualified buyers. In a wellregulated society, in other words, private parties always act on the permission or forbearance of the government; the government's fingerprints are everywhere. ${ }^{85}$

Still, one might respond, in none of these examples did the government actually $d o$ anything to the now-indigent defendant. ${ }^{86}$ The grievance is that the government didn't help him enough, or that it

${ }^{83}$ See Caplin \& Drysdale, 491 US at 625 ("The forfeiture statute does not prevent a defendant who has nonforfeitable assets from retaining any attorney of his choosing.").

${ }^{84}$ Consider generally Mark Kelman, Interpretive Construction in the Substantive Criminal Law, 33 Stan L Rev 591 (1981) (arguing that answers to legal controversies in criminal law often follow from nonrational, interpretive constructs that frame up the controversies out of factual scenarios).

${ }^{85}$ For arguments developing this "baselines" critique, see, for example, Louis Michael Seidman and Mark V. Tushnet, Remnants of Belief: Contemporary Constitutional Issues 49-71 (Oxford, 1996); Cass Sunstein, The Partial Constitution (Harvard, 1993).

${ }^{86}$ Consider, for example, Flagg Brothers, Inc. v Brooks, 436 US 149, 160 n 10 (1978) ("It would intolerably broaden, beyond the scope of any of our previous cases, the notion of state action under the Fourteenth Amendment to hold that the mere existence of a body of property law in a State, whether decisional or statutory, itself amounted to 'state action' even though no process or state officials were ever involved in enforcing that body of law."). 
should have structured society differently. In Luis, by contrast, the government's involvement was not limited to framing the background conditions in which private parties compete for wealth. In Luis, the government took the defendant's money - it reached out and literally "rendered [the defendant] indigent." ${ }^{87}$ And while "a State need not equalize economic conditions" among criminal defendants, prejudice "resulting from a money hurdle erected by a State" is nonetheless unconstitutional. ${ }^{88}$

For essentially the same reasons that the public/private distinction falters in this context, though, this act/omission distinction fails to hold up as well. It is wholly arbitrary to describe the government as having (passively) "allowed" wealthy individuals to bequeath their wealth, having "allowed" private employers to pay low wages or prohibit collective bargaining, or having "allowed" banks to issue irresponsible loans. One could just as readily say that the government, having considered the alternatives, selected (i.e., acted to adopt) rules that favored powerful testators, employers, and banks. ${ }^{89}$ So the government may have "acted" in Luis in a way that reduced the defendant's wealth, but the same can be said in the case of many indigent defendants. ${ }^{90}$

The conceptual problems don't stop there. Suppose we put these academic quibbles to the side and posit that the government really did, in some meaningful sense, take the defendant's money in Luis. One might be tempted to respond, "What else is new?" The government takes money from individuals all the time, without regard for whether they're facing criminal charges, and it's never thought to raise a Sixth Amendment issue. Taxation is only the most salient example. All sorts of agencies - say, the Securities and Exchange Commission or Customs and Border Protection-are empowered to restrain assets in pursuit of their regulatory objectives. They can

\footnotetext{
${ }^{87}$ Luis, $136 \mathrm{~S}$ Ct at 1095 (Breyer, J) (plurality).

${ }^{88}$ Griffin v Illinois, 351 US 12, 23 (1956) (Frankfurter, J, concurring in judgment).

${ }^{89}$ There are numerous sophisticated critiques of the act/omission distinction with respect to the government. See, for example, Susan Bandes, The Negative Constitution: A Critique, 88 Mich L Rev 2271, 2312-13 (1990); Christopher Serkin, Passive Takings: The State's Affirmative Duty to Protect Property, 113 Mich L Rev 345, 372-77 (2014); David A. Strauss, Discriminatory Intent and the Taming of Brown, 56 U Chi L Rev 935, 968 (1989); Cass R. Sunstein and Adrian Vermeule, Is Capital Punishment Morally Required? Acts, Omissions, and Life-Life Tradeoffs, 58 Stan L Rev 703, 719-28 (2005).

${ }^{90}$ See United States v Brodson, 241 F2d 107, 111 (7th Cir 1957) ("[T] the defendant is rendered indigent is immaterial.").
} 
also file civil suit, creating obligations to pay judgments or settlements. ${ }^{91}$ Any of these could be the cause-in-fact of a criminal defendant's indigence. How do we know which government moneyseizures matter for Sixth Amendment purposes?

There has to be some theory akin to proximate cause to sort the constitutionally relevant causes from the irrelevant ones. Yet proximate cause itself is famously circular-there is no reliable way to decide, in a nonarbitrary fashion, which causes are proximate. ${ }^{92} \mathrm{Tem}-$ poral proximity doesn't work. True, the government froze the defendant's assets in Luis the same day it filed criminal charges. ${ }^{93}$ But a large tax bill might have come due the following day, ${ }^{94}$ or the IRS might have filed a jeopardy assessment to restrain the very same assets. ${ }^{95}$ Neither of these occurrences would have sounded Sixth Amendment alarms. ${ }^{96}$ And even if the asset freeze were the closest-in-time occurrence, money is constantly flowing between the government and would-be defendants' hands. Why focus only on the very last exchange rather than letting the government offset the money it froze by pointing to benefits it had conferred upon the defendant, say in the recent past? ${ }^{97}$

Nor does it help to point out that a pretrial asset freeze, unlike the tax examples, is internal to the criminal justice system. For one

${ }^{91}$ See Kathleen F. Brickey, Attorneys' Fee Forfeitures: On Defining "What" and "When" and Distinguishing "Ought" from "Is," 36 Emory L J 761, 769-72 (1987) (giving these and other examples).

${ }^{92}$ See Kelman, 33 Stan L Rev at 642 n 126 (cited in note 84) ("The logic [of proximate cause] says a defendant must cause a harm to be justly punished, and a defendant causes a harm when it is not so accidental as to make it unjust to punish him."). See also Daryl J. Levinson, Framing Transactions in Constitutional Law, 111 Yale L J 1311, 1373 (2002) ("Absent some explanation of why proximate harms and benefits are especially relevant to one another, nexus and germaneness limitations . . . seem to be recommended by little more than the understanding that constitutional law is impossible if transactional frames may be expanded indefinitely.").

${ }^{93}$ Luis, $136 \mathrm{~S}$ Ct at 1104 (Kennedy, J, dissenting).

${ }^{94}$ See 26 USC $\$ 6851$, setting forth a "termination of taxable year" procedure that allows the IRS to demand immediate payment of taxes and levy property under certain conditions.

${ }^{95}$ See 26 USC $\$ 6861$, establishing a "jeopardy assessment" procedure that permits the IRS, in certain circumstances, to assess a tax immediately, creating a lien on the taxpayer's property and allowing the IRS to levy summarily upon it.

${ }^{96}$ See Caplin \& Drysdale, 491 US at 631-32 \& n 8 (citing cases upholding jeopardy assessments "against constitutional attack" and observing that "[c]riminal defendants [ ] are not exempted from federal, state, and local taxation simply because these financial levies may deprive them of resources that could be used to hire an attorney"); Kathleen F. Brickey, Forfeiture of Attorneys' Fees: The Impact of RICO and CCE Forfeitures on the Right to Counsel, 72 U Va L Rev 493, 526-27 (1986) (collecting cases).

${ }^{97}$ See Levinson, 111 Yale L J at 1337 (cited in note 92). 
thing, as a formal matter, that's not necessarily true- the government obtained the pretrial order in Luis in a separate, civil case, not in the criminal case. ${ }^{98}$ But that aside, no one would think collection of a fine imposed in an unrelated criminal matter would violate a defendant's right to counsel of choice in a new prosecution. A transactional approach also fails. What if the government had sued the defendant civilly for the very same set of business transactions in Luis - would the Sixth Amendment block it from collecting on a resulting judgment? I doubt it.

For similar reasons, the distinction between direct and incidental burdens on the right to counsel of choice-most familiar from First Amendment jurisprudence, which typically directs closer judicial scrutiny to the former than the latter ${ }^{99}$ - does not help to identify Sixth Amendment violations, at least without substantially more theorization. ${ }^{100}$ For one thing, it can be awfully difficult to tell the differenceindeed, the Justices disagreed in Luis itself about whether the trial court's order directly or only incidentally burdened the defendant's Sixth Amendment interests. ${ }^{101}$ It is also not clear that direct burdens always raise the same degree of suspicion under the Sixth Amendment as under the First, at least if I am correct that the Sixth Amendment would not block the government from collecting on a judgment awarded against a criminal defendant in a related civil case. ${ }^{102}$

\footnotetext{
${ }^{98}$ Luis, $136 \mathrm{~S}$ Ct at 1104 (Kennedy, J, dissenting).

${ }^{99}$ See Geoffrey R. Stone, Content-Neutral Restrictions, 54 U Chi L Rev 46, 105-14 (1987).

${ }^{100}$ There is reason to question whether the distinction between direct and incidental burdens on constitutional rights translates straightforwardly from the context of "primary conduct rights" (like free speech) to "litigation rights" (like the right to counsel of choice), see Michael C. Dorf, Incidental Burdens on Fundamental Rights, 109 Harv L Rev 1175, 1246-51 (1996); Michael C. Dorf, Facial Challenges to State and Federal Statutes, 46 Stan L Rev 235, 265-66 (1994), or even from one right to another within each of these categories, see Joseph Blocher and Darrell A. H. Miller, What Is Gun Control? Direct Burdens, Incidental Burdens, and the Boundaries of the Second Amendment, 83 U Chi L Rev 295 (2016) (developing a framework specifically to evaluate incidental burdens on Second Amendment rights).

${ }^{101}$ Contrast Luis, $136 \mathrm{~S}$ Ct at 1102 (Thomas, J, concurring in judgment) ("The asset freeze here is not merely an incidental burden on the right to counsel of choice; it targets a defendant's assets, which are necessary to exercise that right, simply to secure forfeiture upon conviction."), with id at 1105 (Kennedy, J, dissenting) ("To be sure, a pretrial restraint may make it difficult for a defendant to secure counsel who insists that high defense costs be paid in advance. That difficulty, however, does not result in a Sixth Amendment violation any more than high taxes or other government exactions that impose a similar burden.").

${ }^{102}$ Some have argued that, when it restrains a defendant's assets pretrial, the government acts with the impermissible purpose of disabling the defense. See, for example, Caplin \& Drysdale, 491 US at 635 (Blackmun, J, dissenting) ("[ [] $\mathrm{t}$ is unseemly and unjust for the Government to beggar those it prosecutes in order to disable their defense at trial.”). This accusation seems unwarranted in general; Congress likely did not legislate with this agenda in mind. See Winick, $43 \mathrm{U}$
} 
Only, then, by relying on multiple, dubious conceptual distinctions and arbitrary framing choices can we explain why freezing the defendant's assets in Luis and forcing her to accept appointed counsel would violate her autonomy interests, yet foisting appointed counsel on an indigent criminal defendant leaves his autonomy undisturbed. And if we cannot explain that, then autonomy fails as a general descriptive theory of the right to counsel of choice.

To venture normative briefly, it is worth observing that, in addition to courting incoherence, distinguishing Luis from the indigence cases on autonomy grounds requires a deeply conservative view of the Sixth Amendment's protections. The position entrenches the status quo by shielding (untainted) assets the defendant possesses immediately before the government moves on them, without regard for how or why the defendant has those assets, while offering no solicitude to the defendant who is indigent when first pursued, without regard for how or why he lacks the assets his wealthier counterpart possesses. It distributes autonomy unequally according to wealth, and regards that wealth as natural rather than as what it isthe product of a lifetime of give-and-take between the individual and his government as well as other private actors on terms the government sets. ${ }^{103}$

c) Countervailing interests.-Many readers, I suspect, will at this point have the impulse to explain the indigence cases by pointing to the government's strong, systemic, countervailing interests. To be sure, the argument goes, choosing lawyers for indigent defendants

\footnotetext{
Miami L Rev at 833-38 (cited in note 13) (reviewing statutory purposes). Still, the prosecutor in a particular case may indeed act with this purpose by, say, targeting for restraint the assets of defendants who retain certain disfavored defense attorneys. See Morgan Cloud, Government Intrusions into the Attorney-Client Relationship: The Impact of Fee Forfeitures on the Balance of Power in the Adversary System of Criminal fustice, 36 Emory L J 817, 829-30 (1987). My tentative view is that such targeting may be prosecutorial misconduct, but that it does not affect the Sixth Amendment calculus under the dominant theories, as any infringement on the defendant's fairness or autonomy interests is the same regardless of the prosecutor's purpose. Consider, for example, United States v Marshall, 526 F2d 1349, 1355 (9th Cir 1975) (rejecting, absent a showing of prosecutorial misconduct, argument that alternative funds be made available when the defendant's assets were under a tax levy).

${ }^{103}$ See Levinson, 111 Yale L J at 1361 (cited in note 92) (describing wealth as "largely dependent on a network of government subsidies and structures ranging from corporate law to government-supported property rights"); Cass R. Sunstein, The Limits of Compensatory fustice, in John W. Chapman, ed, Nomos XXXIII: Compensatory fustice 281, 286, 294, 298-99 (NYU, 1991).
} 
intrudes on those defendants' fairness and autonomy interests, just as in Luis. But it's the only way to run the system. If we let indigent defendants pick, they'll all want Johnnie Cochran. He couldn't possibly take on all that work (even were he alive) and, even if he could, it seems terribly unfair to punish his success with appointed counsel's wages (and implausible for the state to pay his regular rate). The indigence cases, on this view, simply bow to practicality. Fairness and autonomy interests are indeed at stake, but they're overcome by administrative realities. ${ }^{104}$

There is a doctrinal clue supporting this explanation: while indigent defendants do not enjoy the right to counsel of choice, they do retain various fair-trial protections as well as other aspects of the right to control their defense. Indigent defendants, like all others, have the right to effective assistance of counsel, a fair judge, and a prosecutor who toes the line. ${ }^{105}$ "It is also recognized that the accused has the ultimate authority to make certain fundamental decisions regarding the case, as to whether to plead guilty, waive a jury, testify in his or her own behalf, or take an appeal." 106 The point is that granting indigent defendants these rights furthers the same fairness and autonomy objectives thought to motivate the right to counsel of choice but without the concomitant disruption. This suggests that concern about that disruption indeed may have informed the Court's decision to withhold the counsel-of-choice right from indigent defendants.

The concern, however, is likely overblown. Effectuating an indigent defendant's right to counsel of choice could mean something as simple as letting him choose a public defender or panel attorney who is available and willing to represent him-perhaps an attorney with whom he is familiar from a prior case, or one a friend has recom-

\footnotetext{
${ }^{104}$ See Slappy, 461 US at 23 n 5 (Brennan, J, concurring in result) (listing "the State's interest in economy and efficiency" as "considerations that may preclude recognition of an indigent defendant's right to choose his own counsel”); United States v Ely, 719 F2d 902, 905 (7th Cir 1983) (arguing that "indigent defendants cannot be allowed to paralyze the system by all flocking to one lawyer"); Stephen J. Schulhofer, Client Choice for Indigent Criminal Defendants: Theory and Implementation, 12 Ohio St J Crim L 505, 528-29 (2015) (describing cases "assuming that client choice would place unmanageable strains on the management of the criminal docket"). Alternatively, one might argue that "indigent" merely describes the class of individuals who cannot afford any lawyer, and whom the right to counsel of choice, if formally accorded, would not benefit in any way.

${ }^{105}$ Strickland v Washington, 466 US 668, 686 (1984); Bracy v Gramley, 520 US 899, 904-05 (1997); Brady v Maryland, 373 US 83, 87 (1963).

${ }^{106}$ fones $v$ Barnes, 463 US 745, 751 (1983).
} 
mended. ${ }^{107}$ The military, for example, affords an accused the right to representation "by military counsel of his own selection if that counsel is reasonably available." 108 England, Scotland, Wales, and Ontario, Canada give indigent defendants the right to select their attorney, ${ }^{109}$ and both the Judicial Conference of the United States and the American Bar Association at one time suggested the same domestically. ${ }^{110}$ Professors Stephen Schulhofer and David Friedman have outlined the structure of a workable voucher system. ${ }^{111}$ In short, to recognize the indigent defendant's right to counsel of choice, the government need not conscript the bar or foot the bill for Johnnie Cochran. ${ }^{112}$ Administrative concerns, in other words, may explain why the right to counsel of choice must be cabined for indigent defendants, but they cannot explain the current doctrine, which withholds that right altogether.

$* * *$

${ }^{107}$ See, for example, Slappy, 461 US at 22-23 \& n 5 (Brennan, J, concurring in result) (arguing that recognizing "an indigent defendant's interest in continued representation by an appointed attorney with whom he has developed a relationship of trust and confidence" is not impractical); Drumgo v Superior Court of Marin County, 506 P2d 1007, 1013-14 (Cal 1973) (in bank) (Mosk dissenting) (contending that the state should minimize interference with the defendant's choice, particularly where the defendant desires qualified counsel who is ready and willing to serve). For academic arguments supporting a right to counsel of choice for indigent defendants, including refutation or accommodation of the government's presumed interests in efficient administration of the justice system, see Hoeffel, 44 San Diego L Rev at 549 (cited in note 10); Holly, 64 Brooklyn L Rev at 205-17, 224-29 (cited in note 13); Norman Lefstein, In Search of Gideon's Promise: Lessons from England and the Need for Federal Help, 55 Hastings L J 835, 918-19 (2004); Stephen J. Schulhofer and David D. Friedman, Rethinking Indigent Defense: Promoting Effective Representation Through Consumer Sovereignty and Freedom of Choice for All Criminal Defendants, 31 Am Crim L Rev 73 (1993); Peter W. Tague, An Indigent's Right to the Attorney of His Choice, 27 Stan L Rev 73, 80-84, 89-97 (1974); Kenneth P. Troccoli, "I Want a Black Lawyer to Represent Me": Addressing a Black Defendant's Concerns with Being Assigned a White Court-Appointed Lawyer, 20 Law \& Ineq 1, 48-51 (2002).

${ }^{108} 10$ USC $\$ 838(\mathrm{~b})(3)(\mathrm{B})$.

${ }^{109}$ See Schulhofer, 12 Ohio St J Crim L at 508 n 17 (cited in note 104) (collecting sources).

${ }^{110}$ See Judicial Conference of the United States, Committee to Review the Criminal Justice Act, Interim Report (1992), reprinted in 51 Crim L Rep 2335, 2337 (1992); 1 ABA Standards for Criminal Justice, Providing Defense Services $\$ 5-2.3$ (2d ed 1980).

${ }^{111}$ See Schulhofer and Friedman, 31 Am Crim L Rev at 112-22 (cited in note 107). See also Norman Lefstein, Securing Reasonable Caseloads: Ethics and Law in Public Defense 241-49 (ABA, 2011). Inspired by Schulhofer and Friedman's work, Comal County, Texas now permits indigent defendants to choose the publicly funded attorney who will represent them. Schulhofer, 12 Ohio St J Crim L at 509 (cited in note 104).

${ }^{112}$ See Douglas v California, 372 US 353, 357 (1963) ("Absolute equality is not required; lines can be and are drawn and we often sustain them.”). 
Insurmountable problems plague the fairness and autonomy theories of the right to counsel of choice and, indeed, I suspect, any theory of the right premised on individual interests. There is simply too much doctrine that is irreconcilable with a model that straightforwardly balances individual against government interests. In the next part, I offer a system-focused theory that, I argue, better explains the law.

\section{The Antisocialization Alternative}

I begin this part by describing the antisocialization theory and showing how it explains the outcome in Luis. I then illustrate how, unlike the fairness and autonomy theories, an antisocialization theory can also distinguish Luis from all of the prior decisions in which the Court found no counsel-of-choice violation. I conclude by sketching out a plausible normative case for the theory, though I do not attempt a full-throated normative defense (nor am I sure I would want to). Under the antisocialization theory I propose, the right to counsel of choice is plausibly justified not by the advantages it provides to the individuals who invoke it, but by the benefits it confers on other defendants.

\section{A. ILLUSTRATING THE THEORY}

An antisocialization theory conceives of the right to counsel of choice not as a powerful individual protection but rather as a weak, system-oriented safeguard against socialization of the criminal defense bar. ${ }^{113}$ On this view, only when the government advances a theory for restricting the defendant's right to counsel of choice that, if accepted, would allow it to socialize criminal defense by shrinking the private defense bar below some minimal threshold does the counsel-of-choice right prevail over the government's interest. Illustrating how the antisocialization principle can explain the outcome in Luis will make the concept more concrete.

\footnotetext{
${ }^{113}$ Consider Richard H. Fallon Jr. and Daniel J. Meltzer, New Law, Non-Retroactivity, and Constitutional Remedies, 104 Harv L Rev 1731, 1777-91 (1991) (arguing that individual remedies for rights violations are often, but not always, required, so long as the overall system of remedies is "effective in maintaining a regime of lawful government").
} 
The plurality's opinion in Luis actually contains the seeds of an antisocialization theory. The plurality observed, correctly, that a contrary outcome in the case would have "unleash[ed] a constitutional principle that would have no obvious stopping place." ${ }^{114}$ That principle would permit Congress to "write more statutes authorizing pretrial restraints in cases involving other illegal behavior-after all," the plurality pointed out, "a broad range of such behavior can lead to postconviction forfeiture of untainted assets." ${ }^{115}$ And "[e]ven beyond the forfeiture itself, criminal fines can be high, and restitution orders expensive." 116

The Luis plurality may, if anything, have undersold its point. For one thing, Congress has already authorized pretrial restraints more widely than the plurality's language might be read to suggest; it has also, as the plurality notes, widely permitted postconviction forfeiture of substitute assets. ${ }^{117}$ It's only the combination of the twopretrial restraint of substitute assets-that remains rare. Congress could change that with the flick of a pen, adjusting a statutory crossreference or two. It need not "write more statutes," as the plurality suggested, only make the tiniest amendment to some existing ones. The machinery is already in place-Congress just needs to power it on. Restitution, moreover, is mandatory in a huge array of federal cases, including both violent and property crimes. ${ }^{118}$ While the broad federal restitution statute does not presently authorize pretrial restraint of assets, that, of course, is simply a matter of "congressional whim[ ]" that could change at any moment. ${ }^{119}$ Indeed, both Houses of Congress have considered bills that would amend the federal res-

\footnotetext{
${ }^{114}$ Luis, $136 \mathrm{~S}$ Ct at 1094 (Breyer, J) (plurality). Justice Thomas, too, stressed this point. Id at 1098 (Thomas, J, concurring in judgment).

${ }^{115} \mathrm{Id}$ at 1094 (Breyer, J) (plurality).

${ }^{116} \mathrm{Id}$.

${ }^{117}$ For example, the Racketeer Influenced and Corrupt Organizations Act (RICO) authorizes both pretrial restraint of tainted assets and postconviction forfeiture of substitute assets. 18 USC $\$ 1963(\mathrm{e}),(\mathrm{m})$. So does the Controlled Substances Act, 21 USC $\$ 853(\mathrm{e})$, (p). See also 18 USC $\$ 982$ (authorizing forfeiture for a large number of federal offenses and incorporating the procedures in 21 USC $\$ 853$ ). Drug cases alone make up roughly a third of the federal criminal docket. See US Sentencing Commission, Overview of Federal Criminal Cases Fiscal Year $2015 * 2$ (June 2016), archived at https://perma.cc/M2JX-3UQ9 (reporting figure of 31.8 percent).

${ }^{118}$ See 18 USC $\$ 3663 \mathrm{~A}$.

${ }^{119}$ Luis, $136 \mathrm{~S}$ Ct at 1108 (Kennedy, J, dissenting).
} 
titution statute to do exactly that. ${ }^{120}$ Restitution is also mandated, or at least authorized, in every state-court system. ${ }^{121}$ And all that's before we get to criminal fines. ${ }^{122}$

A contrary result in Luis would have allowed the government (federal or state) to attach substantial monetary penalties to any offense-murder, arson, forgery, whatever - and then freeze pretrial assets the defendant may need to pay those penalties. Indeed, given how close we already are to such a regime (as just explained), a contrary result in Luis may well have encouraged this development. One need not imagine improper legislative motives, I should add. Particularly in an age of heightened, bipartisan awareness about the financial and social costs of mass incarceration, the increasing use of monetary penalty schemes as a supplement to or substitute for imprisonment does not seem far-fetched. ${ }^{123}$ Such a development would prevent the vast majority of defendants from retaining counsel and make appointed counsel the norm in all but the most aberrant case (e.g., the super-wealthy defendant). It exaggerates little, then, to conclude that a contrary outcome may have socialized the criminal defense bar. ${ }^{124}$ This is what it means to say that an antisocialization theory explains the outcome in Luis.

\footnotetext{
${ }^{120}$ Restitution for Crime Victims Act of 2007, S 973, 110th Cong, 1st Sess (Mar 22, 2007); Restitution for Crime Victims Act of 2007, HR 4110, 110th Cong, 1st Sess (Nov 7, 2007).

${ }^{121}$ US Dept of Justice, Office for Victims of Crime, Legal Series Bulletin No. 6: Ordering Restitution to the Crime Victim $* 1$ (Nov 2002), archived at https://perma.cc/XJE4-MAPG.

${ }^{122}$ Justice Kennedy, dissenting in Luis, argued that fines present a "separate and distinct" issue from forfeiture, but did not explain why. Luis, $136 \mathrm{~S} \mathrm{Ct}$ at 1108 (Kennedy, J, dissenting) Indeed, at oral argument, Justice Kennedy acknowledged that, "if the government prevails in this case, every State in the union, every locality could say that in the event of . . . any crime involving a bodily injury, that the government is entitled to restrain disposition of assets that might be used for medical care, for pain and suffering." Transcript of Oral Argument at $* 32$, Luis $v$ United States (US Nov 10, 2015) (No 14-419) (available on Westlaw at 2015 WL 8491825). He added, in language resonant with an antisocialization theory, that "this would, in effect, prevent the private bar from-from practicing law unless it does so on a contingent basis." Id at $* 32-33$.

${ }^{123}$ Indeed, aside from the judgment-proof problem, monetary penalties are economically superior to incarceration as a mode of criminal punishment even when the economy is strong. See Frank H. Easterbrook, Criminal Procedure as a Market System, 12 J Legal Stud 289, 293 (1983). See generally David Dagan and Steven Teles, Prison Break: Why Conservatives Turned Against Mass Incarceration (Oxford, 2016).

${ }^{124}$ Writing before Luis, one commentator criticized the Supreme Court's fee-forfeiture decisions for facilitating "socialization of the criminal defense bar." See Matthew R. Lasky, Comment, Imposing Indigence: Reclaiming the Qualified Right to Counsel of Choice in Criminal Asset Forfeiture Cases, 104 J Crim L \& Criminol 165, 180-82 (2014). My argument is that the Court's doctrine prevents socialization of the defense bar, a point that became clear only after Luis.
} 


\section{B. BROADER EXPLANATORY POWER}

More important, unlike the fairness and autonomy theories, an antisocialization theory explains what is unique about Luis; it distinguishes Luis from all of the cases before it. Consider first the disputes concerning the trial court's inherent powers to control litigation. Recall that the trial court has broad discretion to deny a continuance, disqualify an attorney for conflict of interest (even in the face of conflict waivers), and exclude nonlawyers, disbarred lawyers, and out-of-state lawyers from practice-all regardless whether its decision has the effect of depriving the defendant of counsel of choice. What explains these cases (juxtaposed with Luis) is not the relative weakness of the defendant's fairness or autonomy interests, or the strength of the government's need-it's that these are one-off disputes. There's no danger that trial courts will exercise their discretion under these precedents to suffocate the private defense bar. This is because most prosecutions will not present the issues these precedents resolve, and because, even if they did, the trial court's powers enable it to preclude particular attorneys, one at a time, rather than all attorneys the defendant might retain. Nor is there any way for the legislature to amend the law, as it could under a contrary holding in Luis, to give the government the opportunity to exploit the Court's holdings.

The same antisocialization principle explains the distinction between tainted and untainted assets the Court drew in Luis to distinguish Monsanto. The individual-rights theories failed to explain the distinction because "the Government's and the defendant's respective legal interests in those two kinds of property, prior to a judgment of guilt, are exactly the same." 125 Under an antisocialization theory, the explanation is that limiting pretrial asset restraint to tainted assets prevents the government from restraining the defendant's assets in every case, and therefore ensures that some defendants will retain the use of funds to spend on private counsel. The decision in Luis, that is, has the rough-and-ready effect of cabining the government's use of pretrial asset restraint to the subset of crimes that generate monetary proceeds. ${ }^{126}$ Only in these cases - not in most cases of

${ }^{125}$ Luis, $136 \mathrm{~S}$ Ct at 1112 (Kagan, J, dissenting).

${ }^{126}$ See id at 1113 (referring to the plurality's "effort to cabin Monsanto"). 
murder, arson, and so forth - will there be any tainted assets to freeze. And in this way, the doctrine guarantees the continued vitality of the private criminal defense bar. ${ }^{127}$

Finally, the leading theories could not persuasively explain why appointing counsel in Luis would have violated the defendant's right to counsel of choice, but assigning counsel for indigent defendants is unobjectionable. The explanation under an antisocialization theory is straightforward: denying indigent defendants the right to counsel of choice will not starve the private criminal defense bar because indigent defendants, by definition, lack the resources to pay a lawyer and thus to support the bar. The doctrine upholds the right to counsel of choice only when doing so is necessary to prevent socialization of the defense bar; affording the right to indigent defendants is, on this view, a luxury, not a necessity.

\section{NORMATIVE PLAUSIBILITY}

My argument has been that an antisocialization theory explains counsel-of-choice doctrine and that the leading descriptive theories, grounded in the individual defendant's fairness and autonomy interests, do not. My aim is not to defend the antisocialization theory as a normative matter, and I doubt that I would want to. It is, however, worth considering whether there is even a plausible normative justification for antisocialization, "for a theory that seems preposterous as a matter of policy or values does not explain persuasivelyat least not unless one assumes that those who make the law have preposterous values or policy goals." 128

It's not completely obvious that the answer is yes. Efforts to articulate the individualized harm that befalls a defendant who is denied the right to counsel of choice - the project of Part I- have failed. And if we cannot articulate the harm, then why should we mind if

\footnotetext{
${ }^{127}$ It is tempting to speculate that defendants charged with these money-making crimes are the only ones with funds to spend on counsel; in other words, that the only defendants with the financial wherewithal to hire counsel are precisely the ones who'll be disabled from spending. The data, however, appear not to substantiate this supposition. See Harlow, Special Report at $* 5$ (cited in note 74) (reporting that in 1996 rates of appointed counsel were roughly similar across different crime types, with those accused of public-order crimes hiring private attorneys somewhat more frequently than defendants accused of violent, property, or drug crimes).

${ }^{128}$ Stuntz, 88 Colum L Rev at 1292 (cited in note 8).
} 
additional defendants - that last one out of every five-are also denied the choice? ${ }^{129}$

The plurality in Luis does offer one argument on this point. If the government had its way, the plurality observes, all of the newly affected defendants - the defendants who could have afforded counsel previously, but now cannot because the government has frozen their substitute assets - would "fall back upon publicly paid counsel, including overworked and underpaid public defenders." 130 This would "increas[e] the government-paid-defender workload" even further, "render[ing] less effective the basic right the Sixth Amendment seeks to protect." 131

The plurality's basic position seems sound-the last thing publicly funded attorneys need is more work. But to make the plurality's point more than merely rhetorical, and more than marginally relevant to the constitutional calculus, everything must be just so: (1) current resource constraints must not be so severe as to subject indigent defendants to a present and undue risk of ineffective assistance of counsel; (2) the addition of a relatively small number of newly impoverished defendants must then strain the indigent defense system to its breaking point; (3) indigent defense funding levels must not adjust upward in response; and (4) the Court must be willing in the future (as it so far has not been) to hold that funding deficiencies, if severe enough, can violate the Constitution. This strikes me as a dubious set of assumptions.

A better justification would identify reasons to resist socialized criminal defense even assuming the constitutional adequacy of governmentfunded counsel in a socialized world. If public defenders are good enough for the indigent, in other words, are there nevertheless reasons not to have all defendants use them? Or, to frame the issue

\footnotetext{
${ }^{129}$ Similarly, several commentators suggest that it would be dangerous if all criminal defense lawyers were (financially) beholden to the government. See, for example, William J. Genego, The Legal and Practical Implications of Forfeiture of Attorneys' Fees, 36 Emory L J 837, 852 (1987); David Rudovsky, The Right to Counsel Under Attack, 136 U Pa L Rev 1965, 1971 n 24 (1988); Winick, 43 U Miami L Rev at 779-80 \& n 64 (cited in note 13). But if it is acceptable for the state to pay four of every five defense lawyers, what is the problem with having it pay the fifth? These commentators do not say. One possibility is that the private defense bar serves as a bulwark against authoritarianism because it's difficult for the government to control - the government cannot, for example, condition its funding on acquiescence in regulation that dulls its power to challenge government action.

${ }^{130}$ Luis, $136 \mathrm{~S}$ Ct at 1095 (Breyer, J) (plurality)

${ }^{131} \mathrm{Id}$.
} 
slightly differently, does the existence of a private criminal defense bar that services only one in five defendants benefit the other four in any way? ${ }^{132}$ Does privately funded criminal defense create positive externalities?

There are several reasons to think the answer might be yes. I should caution that my discussion of these reasons generalizes about the qualities of the "public" and "private" defense bars. In fact, there is wide variation in experience and skill within both bars alike. The point here is only that some aspects of the private defense bar may redound to the benefit of at least some indigent defendants.

First, the existence of a private criminal defense bar may help attract legal talent to the field. Many public defenders, to be sure, are "cause lawyers" for whom law practice is not primarily an economic enterprise. But some promising young lawyers may be more likely to begin their careers in public defense if they know they can "cash in" down the road at a job in the private defense bar. ${ }^{133}$ One com-

\footnotetext{
${ }^{132}$ Consider the analogy to First Amendment overbreadth, discussed in Richard H. Fallon Jr., Making Sense of Overbreadth, 100 Yale L J 853, 867-70 (1991). Note that a contrary result in Luis would not prevent volunteer counsel-from, say, a public interest organization or law firm-from appearing on a defendant's behalf. A system that precluded even volunteer representation, by requiring defendants to proceed with the lawyer the court appointed to their case, would raise additional difficulties. I will not discuss these problems except to observe that history is replete with examples of locally disfavored defendants relying upon out-of-town, volunteer counsel when local lawyers were too biased, or captured by local interests, to represent them zealously. Powell v Alabama was such a case-after the defendants were denied effective representation at trial, the International Labor Defense organization volunteered to litigate the appeal. Michael J. Klarman, Powell v. Alabama: The Supreme Court Confronts "Legal Lynchings," in Carol S. Steiker, ed, Criminal Procedure Stories 4, 6-7 (Foundation, 2006). See also, for example, Michael Meltsner, Cruel and Unusual: The Supreme Court and Capital Punishment 97 (Random House, 1973) (discussing NAACP involvement in Maxwell v Bishop, 398 US 262 (1970) (per curiam)). See generally David S. Mann, Not for Lucre or Malice: The Southern Negro's Right to Out-of-State Counsel, 64 Nw U L Rev 143, 147 (1969) (asserting that "out-of-state attorneys participated in an average of $68.69 \%$ of the cases, federal and state, involving civil rights and arising in the states of the Fifth Circuit from 1965 to 1968”). Consider also Sanders v Russell, 401 F2d 241 (5th Cir 1968) (invalidating federal district court's restrictions on practice by out-of-state attorneys in civil rights cases).

${ }^{133}$ See Matt Kaiser, 4 Ways to Break into White-Collar Criminal Defense Work (Above the Law, Dec 5, 2013), archived at https://perma.cc/N2VL-LKSN (advising young lawyers seeking private, white-collar defense work to consider federal public defense as a stepping stone); White Collar Defense/Internal Investigations (Ballard Spahr LLP), archived at https:// perma.cc/9JUC-QTUN (advertising "seasoned veterans" including "former public defenders"); Criminal Defense (Loyola U Chi Law Sch), archived at https://perma.cc/X6Z4-2E9K (advising law students that "private defense attorneys ... often gain experience in criminal litigation by working as public defenders"). See also Kenneth Mann, Defending White-Collar Crime: A Portrait of Attorneys at Work 21-22 (Yale, 1985) (describing the high demand across the country for white-collar defense attorneys, which initially targeted federal prosecutors and, later, "a number of attorneys without prosecutorial experience who had worked with leading litigators and received their basic training on the defense side"); William J. Genego,
} 
mentator claims exactly this effect: "If the financial top of the criminal defense market is destroyed by fee forfeiture, fewer and less capable lawyers will enter the field." ${ }^{134}$ Eliminating the prospect of lucrative private defense work in the future may deter some "young lawyers from working in the comparatively low paying public jobs in state public defender . . . offices," ${ }^{135}$ especially because these jobs, unlike stints on the prosecutor's side, are not reliable stepping-stones to politics or private civil firms.

Second, and related, both human and knowledge capital may spill over from the private to the public side. Many new attorneys-especially from elite law schools - head from law school to large law firms, where they can sock away money and learn to practice criminal defense "the right way," typically in a corporate or white-collar setting. As these lawyers tire of law-firm practice, fail to make partner, or simply desire a different course, some pursue careers in public interest work, including public defense. ${ }^{136}$ These transitioning attorneys import into public defender offices the knowledge, skills, and habits they acquired at the firm, and attempt to adapt them to the constraints of their new practice. It is difficult to tell how often this happens, and it may be more common in some public-defense domains than others. But it's not hard to find examples. ${ }^{137}$

The New Adversary, 54 Brooklyn L Rev 781, 787 (1988) (asserting that "rich defendants" who retain counsel affect "the criminal defense bar in general" by bringing "many new attorneys and firms into the market place" who "compete on the basis of their reputations for vigorous and successful defenses to government prosecutions").

${ }^{134}$ Winick, 43 U Miami L Rev at 782 (cited in note 13).

${ }^{135}$ Id. See also Morgan Cloud, Forfeiting Defense Attorneys' Fees: Applying an Institutional Role Theory to Define Individual Constitutional Rights, 1987 Wis L Rev 1, 35 (arguing that, by "driving [the most capable lawyers] from the market, the government would weaken the collective strength of the defense bar" and skew "the balance of power in favor of the government in these - and perhaps most - criminal prosecutions"); Pamela S. Karlan, Discrete and Relational Criminal Representation: The Changing Vision of the Right to Counsel, 105 Harv L Rev 670, 723 (1992) (discussing the "systemic interest in ensuring that skilled lawyers are attracted to and remain in criminal defense practice," which is disserved by permitting the government to disable a defendant's chosen counsel too readily).

${ }^{136}$ Scott L. Cummings, The Politics of Pro Bono, 52 UCLA L Rev 1, 102, 138 (2004) (describing how young lawyers "cycle through the private sector for a short stint in order to pay off debt, build skills, or develop professional relationships," and then "leave the firm, entering other practice sites that provide more supportive environments for their commitments"); Jane E. Tewksbury, The Changing Face of Public Sector Practice: Apprenticeships as a Recruitment Tool, 40 Boston Bar J 12 (Nov-Dec 1996) (reporting that, due to downsizing and attorney interest in work-life balance, "public sector agencies now find that they are the beneficiaries of an increasing number of applications from private sector attorneys with five to seven years legal experience").

${ }^{137}$ See, for example, Parker Douglas and Megan Green, How I Got My Job as a Public Defense Attorney (SJ Quinney College of Law, May 15, 2012), archived at https://perma.cc 
Similarly, well-funded private defense attorneys may develop novel strategies or technologies that, after presentation in open court, publicly funded counsel can emulate. (Consider Barry Scheck's influential cross-examination of the police officer who headed evidence collection as part of O. J. Simpson's defense team, for example. ${ }^{138}$ ) Innovation in defense strategy demands at least two ingredients. The first is the flexibility to experiment. ${ }^{139}$ While socialization may cut against experimentation, it's not fatal-even in a "socialized" world, our decentralized system of public defense permits variation across public defender offices or among appointed counsel. But the second ingredient - resources - would undoubtedly dry up in a socialized system. ${ }^{140}$ The point is that, when wealthy defendants spend huge sums to innovate, in some cases they produce public goods from which indigent defendants also benefit. Likewise, the private market likely breeds subject-matter experts who subsist primarily on high fees from paying clients but who devote a small portion of their practice to pro bono or reduced-rate work on behalf of indigent defendants.

/GAJ8-RX36 (describing federal public defense attorneys "who work their way up through the ranks . . . at law firms doing criminal work"); Kenneth P. Troccoli (Am U Wash College of Law), archived at https://perma.cc/B6E5-TYC6 (listing experience practicing "primarily white-collar criminal defense at three law firms" before becoming a state, and then federal, public defender); President Obama Nominates Four to Serve on the U.S. District Court (White House, Apr 25, 2012), archived at https://perma.cc/AEN5-UH39 (describing now-Judge Jesus G. Bernal, who worked as a litigation associate at a major law firm before joining a federal public defender office). A search of the speakers list at one recent federal public defender conference turned up numerous additional examples. See, for example, Hector Dopico (Bizzabo), archived at https://perma.cc/T52Z-2P37; Mark Drozdowski (Bizzabo), archived at https://perma.cc/W74Q-XB3S; Michael Novara (Bizzabo), archived at https://perma.cc/3V5L -QDES.

${ }^{138}$ Patt Morrison, Barry Scheck on the O.7. Trial, DNA Evidence and the Innocence Project, LA Times (June 17, 2014), archived at https://perma.cc/ZKS2-K4AC; David Margolick, $A$ Simpson Lawyer Makes New York Style Play in fudge Ito's Courtroom, NY Times (Apr 17, 1995), archived at https://perma.cc/TKF9-NHND.

${ }^{139}$ See Caplin \& Drysdale, 491 US at 647 (Blackmun, J, dissenting) (contending that socialization of criminal defense work "too readily would standardize the provision of criminaldefense services," and stressing the social importance of "the maverick and the risk taker and [of] approaches that might not fit into the structured environment of a public defender's office"). Consider, by analogy, the argument that nationalized health care stifles innovation. See, for example, James G. Barlow, Changing the Innovation Landscape in the UK's National Health Service to Meet Its Future Challenges, 2 Innovation and Entrepreneurship in Health 59 (2015)

${ }^{140}$ Lala, 12 NY City L Rev at 258 (cited in note 77 ) (encouraging public defenders to "continue to experiment with innovative ways to provide more effective representation to [their] clients," but cautioning that "bold measures are difficult to take" due to financial constraints). 
Third, if we assume that law enforcement authorities regard private defense counsel as more formidable foes than publicly funded lawyers - even maintaining the prior assumption that governmentpaid counsel are minimally adequate - then the existence of a private defense bar may help deter the type of police and prosecutorial misconduct that defense lawyers frequently litigate. ${ }^{141}$ This would be true to the extent that the authorities may be unsure, at the time the misconduct would occur, which kind of lawyer they will face.

Finally, private defense counsel may affect the content of the law, tending to push it in a defendant-friendly direction. The idea here would be that superior resources enable private counsel to outperform government-paid lawyers in persuading courts that legal doctrine should accommodate defendants' interests, or even just in persuading courts to rule for their clients in ways that end up benefiting future defendants as legal authority. ${ }^{142}$

I have not proved these normative claims, or even close. One or more of them might be wrong. But as a group, they strike me as plausible enough to conclude that justifying the right to counsel of choice on antisocialization grounds would not be "preposterous." 143 That is good enough not to disqualify antisocialization as a descriptive theory.

\section{External Normative Complications}

Scholarly analysis of the Sixth Amendment right to counsel of choice is largely critical. Motivating the criticism is a sense that the Court has been getting the cases wrong. Until Luis, the Court consistently rejected defendants' counsel-of-choice claims, even when the balance of individual and government interests did not clearly

\footnotetext{
${ }^{141}$ See Nancy Leong, Making Rights, 92 BU L Rev 405, 421-29 (2012) (reporting the types of Fourth Amendment claims that are litigated in criminal cases and civil rights lawsuits, respectively).

${ }^{142}$ Lasky, 104 J Crim L \& Criminol at 181-82 (cited in note 124); Andrew Manuel Crespo, Regaining Perspective: Constitutional Criminal Adjudication in the U.S. Supreme Court, 100 Minn L Rev 1985, 2001-05 (2016) (reviewing evidence that quality of advocacy affects case outcomes and opinion content). See also Einer R. Elhauge, Does Interest Group Theory fustify More Intrusive fudicial Review?, 101 Yale L J 31, 66-87 (1991) (arguing that the litigation process is susceptible to the same disproportionate influence of those who can organize, mobilize resources, and overcome free-rider problems as is the political process).

${ }^{143}$ Stuntz, 88 Colum L Rev at 1292 (cited in note 8).
} 
favor the state. ${ }^{144}$ My claim is that the Court's decisions are explicable upon the realization that the doctrine treats counsel of choice not as an individual right at all, but instead as a system-level safeguard against a socialized criminal defense bar. Were I asked to predict the Court's next counsel-of-choice decision, I would-on the admittedly controversial assumption that most Justices, in most cases, make some effort to decide disputes consistently with the pattern of preceding decisions ${ }^{145}$ - look to this explanation before the fairness and autonomy theories commentators have assumed the Court has been ineptly attempting to implement. And were I to critique the doctrine on normative grounds, I would consider whether antisocialization ought to delineate its bounds.

I want here, however, to turn to a different normative point: There are reasonable arguments, based on separate constitutional principles, independent from the right to counsel of choice, that several of the precedents discussed above are incorrect. The first is Monsanto. Justice Kagan, dissenting in Luis, characterized Monsanto as "a troubling decision," and I agree. ${ }^{146}$ The reason is that, as Justice Kagan points out, at the moment the government freezes the defendant's assets pretrial-based on a showing of probable cause to believe the assets will be proved forfeitable - "the presumption of innocence still applies." ${ }^{147}$ And while it's true, as the Monsanto Court reasoned, that the government may sometimes restrain persons pretrial "where there is a finding of probable cause to believe that the accused has committed a serious offense," 148 the analogy is less persuasive than it appears.

\footnotetext{
${ }^{144}$ See, for example, Garcia, 29 Am Crim L Rev at 86 (cited in note 14) ("The Court's jurisprudence in this sphere is seriously flawed, reflecting its strong preference for crime control and efficiency imperatives and its corresponding depreciation of the critical role of the defense attorney in the criminal process."); Note, 124 Harv L Rev at 1558 (cited in note 23) (criticizing the doctrine for doing "almost no work whatsoever").

${ }^{145}$ See Ronald Dworkin, Law's Empire 228-32, 397-99 (Harvard, 1986) (comparing judges to authors of a "chain novel"); David A. Strauss, Common Law Constitutional Interpretation, 63 U Chi L Rev 877, 883 (1996) ("Mostly the courts decide cases by looking to what the precedents say.").

${ }^{146}$ Luis, $136 \mathrm{~S}$ Ct at 1112 (Kagan, J, dissenting).

${ }^{147}$ Id, quoting Kaley v United States, 134 S Ct 1090, 1096 (2014). See also United States $v$ Al Sharaf, 2015 WL 4238784, *2-3 (DDC) (citing the defendant's presumption of innocence in rejecting the government's request for pretrial restraint of assets the defendant might need to pay restitution if convicted).

${ }^{148}$ Monsanto, 491 US at 615-16.
} 
First, while a criminal indictment may issue based on probable cause, pretrial restraint of the accused "cannot be justified by the fact of the indictment alone." ${ }^{49}$ The government must also show, by clear and convincing evidence at an adversarial hearing, that "no condition or combination of conditions will reasonably assure the appearance of the person [for trial] and the safety of any other person and the community." 150 Second, it would not be difficult to ensure that the defendant's assets be used only for their intended purpose. The assets could be placed in escrow and released to the defendant's attorney upon submission of a reasonable request for fees. Upon resolution of the case, the balance would be returned to the defendant or forfeited, as appropriate. ${ }^{151}$ Such an arrangement would advance the legislative aims of punishing crime and disgorging its proceeds but not the impermissible aim of hobbling the accused's ability to defend himself. ${ }^{152}$

Yet simply rolling back Monsanto may not be satisfactory either. There is the nagging problem of the hypothetical robbery suspect, first raised by the Court in Caplin \& Drysdale. "A robbery suspect," the Court there pointed out, "has no Sixth Amendment right to use funds he has stolen from a bank to retain an attorney to defend him if he is apprehended. The money, though in his possession, is not rightfully his," the Court continued, and so "the Government does not violate the Sixth Amendment if it seizes the robbery proceeds and refuses to permit the defendant to use them to pay for his defense."153

\footnotetext{
${ }^{149}$ Caplin \& Drysdale, 491 US at 654 (Blackmun, J, dissenting).

${ }^{150} 18$ USC $\$ 3142$ (e)-(f). See also Kaley, 134 S Ct at 1111 (Roberts, CJ, dissenting) ("Retaining one's counsel of choice ensures the fundamental fairness of the actual trial, and thus may be far more valuable to a criminal defendant than pretrial release.").

${ }^{151}$ See Cloud, 36 Emory L J at 832 (cited in note 102) ("Methods exist to ensure that a rule exempting fees from forfeiture would not be abused by defendants and unscrupulous attorneys.").

${ }^{152}$ See Caplin \& Drysdale, 491 US at 652 (Blackmun, J, dissenting) ("[W]eakening the ability of an accused to defend himself at trial ... is not a legitimate government interest that can be used to justify invasion of a constitutional right."), quoting United States v Monsanto, 852 F2d 1400, 1403 (2d Cir 1988) (Feinberg concurring) (quotation marks omitted); Winick, 43 U Miami L Rev at 835-37 (cited in note 13) (discussing the government's various interests in forfeiture and arguing that none is substantially weakened by allowing defendants to pay bona fide attorney fees); Lisa F. Rackner, Note, Against Forfeiture of Attorneys' Fees Under RICO: Protecting the Constitutional Rights of Criminal Defendants, 61 NYU L Rev 124, 140 (1986). But see Caplin \& Drysdale, 491 US at 630 (questioning but ultimately agreeing with "[ $t]$ he notion that the Government has a legitimate interest in depriving criminals of economic power, even insofar as that power is used to retain counsel of choice").

${ }^{153}$ Caplin \& Drysdale, 491 US at 626.
} 
One might respond, of course, that the robbery suspect is only that - a suspect - and the funds he wishes to spend, only alleged robbery proceeds. ${ }^{154}$ It is not difficult, though, to conjure factual scenarios in which this position would become untenable. To reach a solution that accommodates not only the defendant's right to counsel of choice (whatever it means) and the government's interest in forfeitable assets, but also the presumption of innocence, the Court must surface all of these competing interests. It must resist the temptation to rely on a false binary in which money is either "stolen" or wholly "innocent." Probably some heightened burden of proof for pretrial asset restraint, beyond probable cause, is in order. ${ }^{155}$

The second precedent-or principle, really-that appears to contravene separate constitutional values, apart from what counselof-choice doctrine ought to require, is the principle that indigent defendants enjoy no control whatsoever over who represents them (apart from the option to eschew counsel altogether). Even when the Constitution does not require the state to furnish criminal defendants a particular right, when the state voluntarily undertakes to do so, the Equal Protection Clause demands that it afford the right to wealthy and poor alike. ${ }^{156}$ The mandate is not that all defendants be put on equal footing, ignoring, for example, "the harsh reality that the quality of a criminal defendant's representation frequently may turn on his ability to retain the best counsel money can buy." 157 The discriminatory effects of wealth disparities are not unconstitutional, in other words. But "discrimination against 'indigents' by name" is another matter. ${ }^{158}$

The principle denying indigent defendants any right to counsel of choice is of this latter, more pernicious sort. The Court in these cases does more than nod to the "harsh reality" that wealthy crim-

\footnotetext{
${ }^{154}$ See Lasky, $104 \mathrm{~J}$ Crim L \& Criminol at 183-85 (cited in note 124) (attacking the bank robber analogy).

${ }^{155}$ See Terrance G. Reed and Joseph P. Gill, RICO Forfeitures, Forfeitable "Interests," and Procedural Due Process, 62 NC L Rev 57, 91-92 (1983) (advocating a clear-and-convincingevidence standard for pretrial asset restraint).

${ }^{156}$ The canonical cases are Douglas v California, 372 US 353 (1963), which concerned the provision of appellate counsel in felony cases, and Griffin v Illinois, 351 US 12 (1956), about access to a trial transcript or other record adequate to afford effective appellate review.

${ }^{157}$ Caplin \& Drysdale, 491 US at 630, quoting Slappy, 461 US at 23 (Brennan, J, concurring in result).

${ }^{158}$ Griffin, 351 US at 35 (Harlan, J, dissenting).
} 
inal defendants can afford fancier lawyers than poor ones. It withholds the right to counsel of choice from indigent defendants altogether. Perhaps the thinking is that affording indigent defendants a say in the matter is impracticable. Yet there are ways to structure the appointment of counsel, discussed above, that accommodate administrative realities while according indigent defendants a measure of choice. ${ }^{159}$ This is an accommodation we ought to pursue and, indeed, the Fourteenth Amendment would seem to impel us to do so. ${ }^{160}$

If one can say nothing else, it is that the right to counsel of choice is grossly undertheorized, particularly for an entitlement said to embody the "root meaning" of the "mo[st] essential" criminal procedure right. ${ }^{161}$ Perhaps the Court's decision in Luis deserves the praise it has received. ${ }^{162}$ But it looks to me a lot like selective empathy that is, at bottom, difficult to justify by notions of individual desert. Seeing the doctrine now for what it really does, we are positioned to consider whether the right is best limited, as it is today, to effectuating system architecture, or whether it ought to be given wider compass to benefit all defendants more directly.

\footnotetext{
${ }^{159}$ See text accompanying notes $107-11$.

${ }^{160}$ For a similar argument, see Tague, 27 Stan L Rev at 88-89 (cited in note 107).

${ }^{161}$ Lakeside v Oregon, 435 US 333, 341 (1978) ("In an adversary system of criminal justice, there is no right more essential than the right to the assistance of counsel.").

${ }^{162}$ See, for example, Mark Joseph Stern, The Supreme Court Affirms Your Right to Hire a Lawyer of Your Choosing (Slate, Mar 30, 2016), archived at https://perma.cc/84Y7-MW64.
} 